ENERGY DIVISION

\title{
PUBLIC-POLICY RESPONSIBILITIES IN A RESTRUCTURED ELECTRICITY INDUSTRY
}

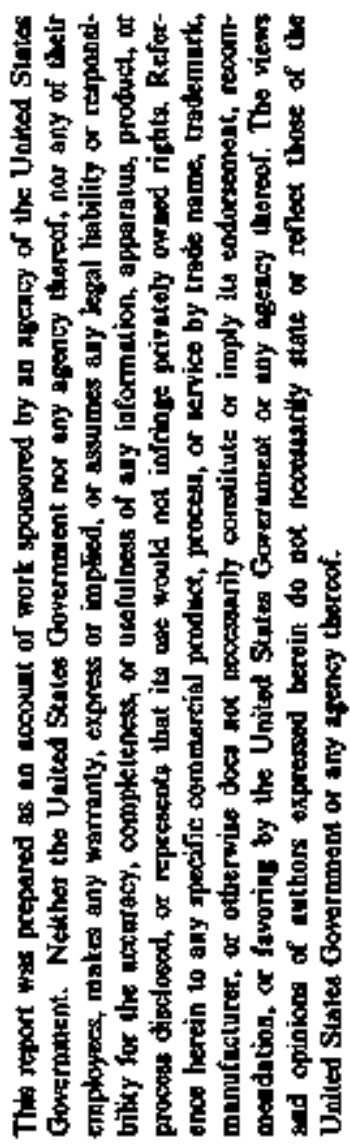

\author{
BRUCE TONN \\ ERIC HIRST \\ DOUGLAS BAUER \\ June 1995 \\ Sponsored by \\ Office of Energy Efficiency and Renewable Energy \\ U.S. Department of Energy \\ OAK RIDGE NATIONAL LABORATORY \\ Oak Ridge, Tennessee 37831 \\ Inanaged by \\ MARTIN MARIETTA ENERGY SYSTEMS, INC. \\ for the \\ U.S. DEPARTMENT OF ENERGY \\ under contract No. DE-AC05-84OR21400
}





\section{DISCLAIMER}

Portions of this document may be illegible in electronic image products. Images are produced from the best available original document. 


\section{CONTENTS}

Page

SUMMARY $v$

LIST OF ACRONYMS $\ldots \ldots \ldots \ldots \ldots \ldots \ldots \ldots \ldots \ldots \ldots \ldots, \ldots \ldots, \ldots \ldots$

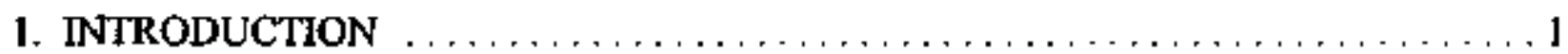

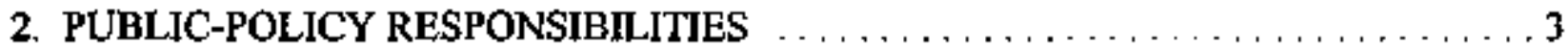

REVIEW OF SUGGESTED RESPONSIBILITIES $\ldots \ldots \ldots \ldots \ldots \ldots \ldots, 3$

CONSOLIDATED FRAMEWORK OF RESPONSIBILITIES $\ldots \ldots \ldots \ldots \ldots 5$

COSTS OF MEETING RESPONSIBILITIES $\ldots \ldots \ldots \ldots \ldots \ldots \ldots \ldots \ldots$

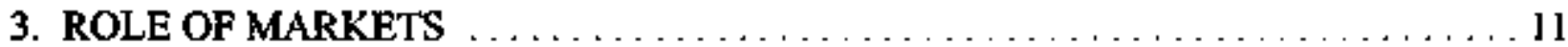

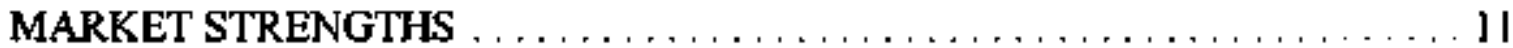

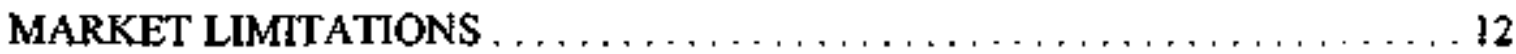

FUTURE ELECTRIC-INDUSTRY STRUCTURES $\ldots \ldots \ldots \ldots \ldots \ldots \ldots, 13$

MAPPING MARKETS ONTO RESPONSIBILITIES $\ldots \ldots \ldots \ldots \ldots \ldots \ldots, 16$

4. ROLE OF GOVERNMENTS ............................. 2]

CRITERIA FOR EVALUATING GOVERNMENT RESPONSES $\ldots \ldots \ldots \ldots 21$

POTENTIAL ENABLING MECHANISMS $\ldots \ldots \ldots \ldots \ldots \ldots \ldots \ldots \ldots, 22$

GOVERNMENT IMPLEMENTATION $\ldots \ldots \ldots \ldots \ldots \ldots \ldots \ldots \ldots$

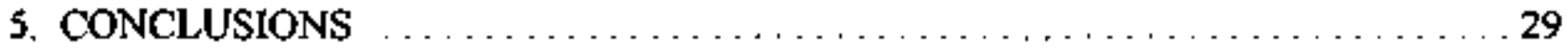

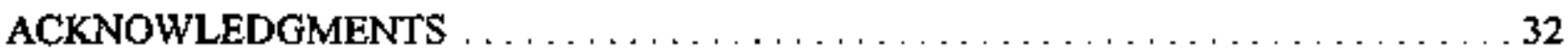

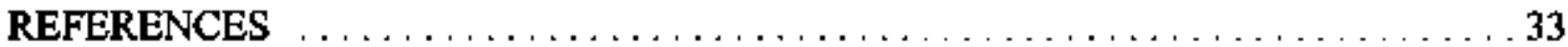

APPENDIX A: WORKSHOP PARTICIPANTS $\ldots \ldots \ldots \ldots \ldots \ldots \ldots \ldots \ldots \ldots$

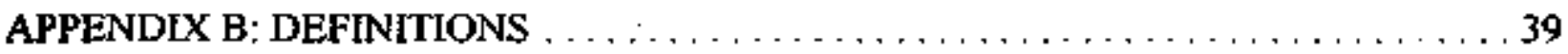





\section{SUMMARY}

Stale and federal regulators, private and public utilities, power marketers and brokers, energy-service companies, electricity consumers, and other interrested parties are considering how to restructure the U.S. electricity industry. The treatment of potentially "stranded benefits" is increasingly an important issue in these discussions.

We organized and conducted a workshop on Public-Policy Responsibilities and ElectricIndustry Restructuring: Shaping the Research Agenda in April 1995 to examine these issues. This report, based in large part on discussions at the workshop, proposes a three-part framework for considering public-policy functions in a restructured industry. The framework consists of values, objectives, and actions taken to meet the underlying objectives (Table S-1).

We used this framework to examine the ability of an industry with full retail wheeling to meet these objectives. The industry is likely to cut costs and increase customer choices in products, services, and prices. These changes should improve overall economic efficiency and enhance industrial competitiveness. With only modest oversight from the Federal Energy Regulatory Commission, the industry will likely maintain reliable electric service and provide nondiscriminatory access to the monopoly elements of the electric system (i.e., the transmission and distribution systems).

On the other hand, responsibilities for long-term functions, such as energy research, resource-portfolio management, energy efficiency, and renewable resources will likely be shared between the industry and governments. We anticipate the use of different actions (mechanisms) to achieve the underlying objectives that these functions have historically mel. For example, regulators may impose fewer requirements to acquire energy-efficiency and renewable resources and, instead, impose stricter environmental requirements. Imposing a national cap on annual $\mathrm{CO}_{2}$ emissions might be a more effective way to slow global waming than the indirect route of requiring DSM programs and renewable setasides. Finally, governments may have to take the lead to ensure that consumers, especialty small consumers who lack narket power, are treated fairly and given adequate minimum services. In some cases, governments may use taxes to fund programs, such as low-income weatherization services. Thus, costs may shift from electricity consumers to citizens in general as some government responsibilities shift from utilities and state regulatory commissions to other state agencies.

Our review of the workshop discussions and other sources suggests that the electricity industry of the future can achieve economic-efficiency gains and, at the same time, continue to provide the public-policy functions that it now does. 
Table S-1. Consolidated framework of public-policy responsibilities

\begin{tabular}{|c|c|c|c|c|c|c|c|c|c|c|c|}
\hline \multirow[b]{2}{*}{$\begin{array}{l}\text { Values and } \\
\text { objectives }\end{array}$} & \multicolumn{11}{|c|}{ Actions } \\
\hline & $\begin{array}{l}\text { Research } \\
\& \\
\text { develop- } \\
\text { ment }\end{array}$ & $\begin{array}{l}\text { Systeti } \\
\text { reliabitity }\end{array}$ & $\begin{array}{l}\text { Portfoliofrisk } \\
\text { management }\end{array}$ & DSM & $\begin{array}{l}\text { Non- } \\
\text { discriminatory } \\
\text { trantsmission } \\
\text { atcess }\end{array}$ & $\begin{array}{l}\text { Low* } \\
\text { incorne } \\
\text { progeams }\end{array}$ & $\begin{array}{l}\text { Minimum } \\
\text { service } \\
\text { standards }\end{array}$ & $\begin{array}{l}\text { Consurater } \\
\text { prolection }\end{array}$ & $\begin{array}{l}\text { Foir trealuent } \\
\text { of stranded } \\
\text { commitments }\end{array}$ & $\begin{array}{l}\text { Renewable } \\
\text { energy }\end{array}$ & $\begin{array}{l}\text { Pollution } \\
\text { reduction }\end{array}$ \\
\hline \multicolumn{12}{|l|}{ Econortic progress } \\
\hline $\begin{array}{l}\text { Economic } \\
\text { efficiency }\end{array}$ & $\checkmark$ & $\checkmark$ & & $f$ & $\checkmark$ & & & & $\checkmark$ & & \\
\hline $\begin{array}{l}\text { Industrial } \\
\text { competitiveness }\end{array}$ & $\gamma$ & 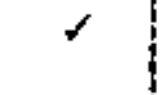 & $\checkmark$ & $\downarrow$ & $\checkmark$ & & & & & $\checkmark$ & $\checkmark$ \\
\hline $\begin{array}{l}\text { Ecomomic } \\
\text { development }\end{array}$ & $\checkmark$ & $\checkmark$ & $\checkmark$ & $\checkmark$ & $\checkmark$ & & & & & $\checkmark$ & $\checkmark$ \\
\hline Cusstomer choice & $\checkmark$ & $\checkmark$ & & $\checkmark$ & & & $\checkmark$ & & & $\checkmark$ & \\
\hline \multicolumn{12}{|l|}{ Social equity } \\
\hline $\begin{array}{l}\text { Equiteble sharing of } \\
\text { casts and benefils }\end{array}$ & & $\checkmark$ & $\checkmark$ & 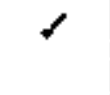 & $\gamma$ & $\checkmark$ & $\checkmark$ & $\checkmark$ & $\checkmark$ & & \\
\hline Public participalion & & & $\checkmark$ & $\checkmark$ & & & & $\checkmark$ & $\checkmark$ & & \\
\hline $\begin{array}{l}\text { Fair-1rade } \\
\text { safeguards }\end{array}$ & & & & & $\checkmark$ & & & $r$ & & & \\
\hline $\begin{array}{l}\text { Protection of hurnan } \\
\text { belfare }\end{array}$ & $\checkmark$ & & $\checkmark$ & & & $\checkmark$ & 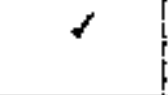 & $\checkmark$ & & & 1 \\
\hline \multicolumn{12}{|c|}{ Environmental stewardship } \\
\hline $\begin{array}{l}\text { Clean clecuriciny } \\
\text { generstion and } \\
\text { delivery }\end{array}$ & $\checkmark$ & & $\checkmark$ & $\checkmark$ & $\checkmark$ & & & & $\checkmark$ & $\checkmark$ & $\checkmark$ \\
\hline $\begin{array}{l}\text { Regional } \\
\text { environnmental } \\
\text { qualıtín }\end{array}$ & $\checkmark$ & & & $\checkmark$ & & & & & & $\checkmark$ & $\checkmark$ \\
\hline
\end{tabular}




\section{LIST OF ACRONYMS}

DSM Demand-side management

EIA Energy Information Administration

FERC Federal Energy Regulatory Commission

IOU Investor-owned utility

IRP Integrated resource planning

PUC Public utility commission

RTG Regional transmission group

R\&D Research and development 


\section{INTRODUCTION}

The U.S. electric-utility industry is undergoing a major restructuring, from a vertically integrated, retail-monopoly-franchise, highly regulated industry to a less regulated, deintegrated, competitive-market-dominated industry. Like other formerly regulated and now deregulated U.S. industries, the electric industry is "affected with the public interest." In exchange for reasonable rates of retum on invested capital, regulators require the regulated firms to provide quality service at reasonable rates and to meet public-policy (social) goals that extend beyond the firm's basic business of producing and delivering electricity (Kahn 1988). As evidenced by the lists of public-policy responsibilities in Chapter 2, we believe that the electric industry is unique in the scope of the public-policy responsibilities it has shouldered for many decades. Because of this scope and history, it is important to consider how the mosaic of public interests would be satisfied during industry transition and under various restructuring alternatives.

In this report, we identify and define the key public-policy values, objectives, and actions that the U.S. electricity industry currently meets. We also discuss the opportunities for meeting these objectives in a restructured industry that relies primarily on market forces rather than on government mandates. And we discuss those functions that governments might undertake, presumably because they will not be fully met by a restructured industry on its own.

These discussions are based on a variety of inputs. The most important inputs came from participants in an April 1995 workshop on Public-Policy Responsibilities and Electric lndustry Restructuring: Shaping the Research Agenda ${ }^{*}$ Other sources of information and insights include the reviews of a draft of this report by workshop participants and others and the rapidly growing literature on electric-industry restructuring and its implications.

One of the major concerns about the future of the electricity industry is the fate of numerous social and environmental programs supported by today's electric utilities. Many people worry that a market-driven industry may not meet the public-policy objectives that electric utilities have met in the past. Examples of potentially at-risk programs include demandside management (DSM), renewable energy, low-income weatherization, and fuel diversity.

Workshop participants represented electric utilities, public utility commissions (PUCs), state energy offices, public-interest groups, other energy providers, and the research community

"The April 1995 workshop was a follow-on to one held in July I994 on IRP and the Electric Irxistry of the Future, which focused on defining altentalive future industry scemarios and assessing research issues associated with each scenario (Tonn, Hirst, and Batucr 1994). Oak Ridge National Laboratory ran both workshops with funding from the U.S. Department of Energy. 
(Appendix A). The three major goals of the workshop were to: (1) identify important publicpolicy values and objectives that should be met by a restructured electric indusiry; (2) assess whether markets can meet these objectives; and (3) assess the roles of governments in meeting these objectives. To help achieve these goals, we posed eight questions to the workshop participants:

1. What public-policy objectives are met by today's U.S. electric indusiny?

2. What are the definitions of these public-policy objectives?

3. Why are the public-policy objectives important to society?

4. Approximately how much money are electric thilities currently spending to meet these public-policy objectives?

5. Which objectives will probably be met by a market-driven electric industry, and why?

6. What industry-restructuring altematives should be used to help address the objectives identified by Question 5?

7. Which objectives deserve the highest priority attention of government?

8. Which objectives are appropriately and easily achievable by govermment, and why?

Chapter 2 discusses the public-policy responsibilities to be met by the electricity industry. We first present a summary of lists of public-policy responsibilities, based on a review of the recent literature. Then, we present a framework composed of values, objectives, and actions for organizing the responsibilities, followed by an overview of what the industry now spends to meet these responsibjlities. Appendix B defines the values, objectives, and actions developed here.

Chapter 3 examines the role of markets in meeting public-policy responsibilities. We begin with a general discussion of the virtues of markets and the factors that may affect the ability of markets to meet public-policy responsibilities. Then, we present an altenative market structure for a competitive industry. We use this alternative to assess the likelihood that markets will meet specific responsibilities.

Chapter 4 examines the role of governments in meeting public-policy responsibilities. We first offer criteria for evaluating the ability of governments to meet responsibilities. A potential list of public-policy actions follows. Finally, we evaluate the list using these criteria. Chapter 5 concludes with observations on the importance, complexity, and resolution of the public-policy questions confronted by stakeholders in the electric industry. 


\section{PUBLIC-POLICY RESPONSIBILITIES}

The term "public-policy responsibility" refers to issues, considerations, and programs of public interest that have been addressed and/or provided by regulated and vertically integrated electric utilities. Policy makers feel a responsibility for ensuring that inssifutions are in place to meet these objectives. Within this framework, markets are institutions, as are utilities and local, state, and federal governments. One vision of electric-industry restructuring calls for replacing the institution of a vertically integrated and highly regulated utility with new market institutions and possibly other institutions [e.g., nonprofit research organizations and regional transmission groups (RTGs)] to ensure that public-policy functions are met. Identifying these values and objectives is vital to implementing the associated actions.

\section{REVIEW OF SUGGESTED RESPONSIBILITIES}

Table 1 presents six proposed sets of public-policy responsibilities, 28 in all, proposed by people who represent different viewpoints. Tiemey (1994) represents the perspective of the federal government. The Califomia Public Utilities Commission (1994) and New York Public Service Commission (1994) are state regulators. Cullen et al. (1994) and Hamrin et al. (1994) are researchers. The Electricity Consumers Resource Council (1994) takes an industrial viewpoint.

Several observations can be made about the tabte. First, many responsibilities are in several lists, such as environmental protection, energy efficiency, and fait and stable prices. Second, no responsibility is found in every list, which indicates a potential difficulty in arriving at a consensus list. Third, many of the concepts overlap one another, such as economic efficiency and industrial competitiveness. Fourth, many concepts seem difficult to define, such as equity and service quality and choice.

Based on these lists, we presented these responsibilities to the workshop participants in four categories:

"Bellah et al. (1992) exptain the concept of institulion: "... an institulion is a patters of expected action of individaals or groups cnfored by social sanclions, bolh posilive and negative ... Individualistic Americans fear that institutions impinge on their lreedon ... Instilutions are nomative palterns emboddad in and enforced by laws and mores (informal custoins and practices). In common usage the term is also used to apply to concrete organizations. Organizations certainly loom large in our lives, but if we think only of organizations and not of institutions we may gently oversimplify our problems. The corporation is a central institution in American life." 
Table 1. Summary of suggested public-policy responsibilities

\begin{tabular}{|c|c|c|c|c|c|c|}
\hline $\begin{array}{l}\text { Public-policy } \\
\text { responsibilities }\end{array}$ & Tierney & $\begin{array}{l}\text { Cullen } \\
\text { et al. }\end{array}$ & $\begin{array}{l}\text { California } \\
\text { PUC }\end{array}$ & $\begin{array}{l}\text { Hamrin } \\
\text { et al. }\end{array}$ & $\begin{array}{l}\text { Electricity } \\
\text { Consumers } \\
\text { Resource } \\
\text { Council } \\
\end{array}$ & $\begin{array}{l}\text { New York } \\
\text { Public } \\
\text { Service } \\
\text { Commission }\end{array}$ \\
\hline Economic efficiency & $\checkmark$ & $\checkmark$ & & $\checkmark$ & & $\checkmark$ \\
\hline Industrial competitiveness & $\checkmark$ & & & & & \\
\hline Economic development & & & $\checkmark$ & & $\checkmark$ & $\checkmark$ \\
\hline Fair-trade safeguards & & & & & & $\checkmark$ \\
\hline $\begin{array}{l}\text { Nondiscriminatory } \\
\text { transmission access }\end{array}$ & & & $\checkmark$ & & & \\
\hline $\begin{array}{l}\text { Fair treatment of stranded } \\
\text { assets }\end{array}$ & $\checkmark$ & & $\checkmark$ & $\checkmark$ & & $\checkmark$ \\
\hline Service quality and choice & & & $\checkmark$ & & & $\checkmark$ \\
\hline Environmental protection & $\checkmark$ & $\checkmark$ & $\gamma$ & & $\checkmark$ & $\checkmark$ \\
\hline Externalities & & & & & $\checkmark$ & \\
\hline Fuel diversity & $\checkmark$ & & $\checkmark$ & & $\checkmark$ & $\checkmark$ \\
\hline Renewable energy & $\checkmark$ & $\checkmark$ & $\checkmark$ & $\checkmark$ & & \\
\hline Technological innovation & $\checkmark$ & & $\checkmark$ & $\checkmark$ & & $\checkmark$ \\
\hline Research \& development & $\checkmark$ & & & & & $\checkmark$ \\
\hline $\begin{array}{l}\text { System relitability and } \\
\text { integrity }\end{array}$ & $\checkmark$ & $\checkmark$ & $\checkmark$ & & & $\checkmark$ \\
\hline Low-emission vehicles & & & $\checkmark$ & & & \\
\hline Energy efficiency & & $\checkmark$ & $\checkmark$ & $\checkmark$ & $\checkmark$ & $\checkmark$ \\
\hline Cost-effective DSM & $\checkmark$ & & $\checkmark$ & & & \\
\hline $\begin{array}{l}\text { Integrated resource } \\
\text { planring principles }\end{array}$ & $\checkmark$ & & & & & \\
\hline $\begin{array}{l}\text { Low-incorne } \\
\text { weatherization and other } \\
\text { programs }\end{array}$ & & $\checkmark$ & $\checkmark$ & & $\checkmark$ & \\
\hline Winter moratoria & & $\checkmark$ & & & & \\
\hline Equity & $\checkmark$ & & & $\checkmark$ & & \\
\hline Fair and stable prices & & $\checkmark$ & $\gamma$ & $\checkmark$ & & $\checkmark$ \\
\hline Public participation & & & & & $\checkmark$ & $\checkmark$ \\
\hline Minority businesses & & & $f$ & & & \\
\hline Public safety & & $\checkmark$ & 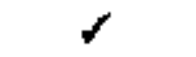 & & & $\checkmark$ \\
\hline Consumer protection & & & & $\checkmark$ & & $\checkmark$ \\
\hline $\begin{array}{l}\text { Forward-looking labor- } \\
\text { management interaction }\end{array}$ & & & & & & $\checkmark$ \\
\hline Universal basic service & & & & $\checkmark$ & & $\checkmark$ \\
\hline
\end{tabular}


- Economic (e.g., economic efficiency and industrial competitiveness);

- Environmental (e.g., renewable energy and environmental protection);

Technological [e.g., research and development (R\&D) and tow-ernission vehicles]; and Public welfare (e.g., equity and low-income weatherization).

This classification scheme and list prompted vigorous discussion on several points. First, by putting the responsibilities into these four categories, one runs the risk of neglecting the interactions among responsibilities. For example, DSM can be viewed both as an economic action and as environmental protection. Second, terminology is an issue. The list contains responsibilities that are not comparable. For example, equity tepresents a qualitatively different concept than low-income weatherization. Third, participants hold different views on how the world works. For example, some participants think of people primarily as citizens, whereas others ihink of people primarily as consumers and producers in a market economy. These and other differences lead to different uses of the terms listed in Table 1. Fourth, the lists did not contain all the responsibilities that the participants felt are important.

\section{CONSOLIDATED FRAMEWORK OF RESPONSIBILITIES}

Participants revised the list of Table $\mid$ responsibilities and developed frameworks to understand how the responsibilities relate to one another. Table 2 presents a consolidated framework, based on the workshop discussions, subsequent feedback from participants and others, and our own views. The framework aims to overcome difficulties with semantics, express the connextedness of the world, and reduce the number of responsibitities to a manageable number.

The framework contains three components: values, objectives, and actions. Values are fundamental guiding principles (or standards) of life. Values can be viewed as "great ideas," such as truth, goodness, beauty, liberty, equality, and justice (Adler 1981). Commonly held fundamental values are essential bonds among people. As such, values represent building blocks of public policy. Objectives are broad goals related to the expression of the fundamental values. Objectives are what we work for. And actions are purposeful behaviors intended to achieve objectives. Actions are tangible and involve people doing things. Appendix $B$ defines the values, objectives, and actions listed in Table 2.

Table 2 is best read from the left to the right and then up the columns to emphasize that the 11 actions are valuable not in their own right but only insofar as they help meet one or more of the 10 objectives. Thus, several actions can satisfy multiple objectives. For exarnple, R\&D can bolster all four economic objectives, as well as increase protection of human welfare and satisfaction of the environmental objectives. Renewable energy and DSM have similar profiles. In general, actions to achieve economic progress can also, under certain circumstances, lead to environmental stewardship. Several actions pertain mainly to social-equity objectives, such as low-income programs, minimum service standards, and consumer protection. 
Table 2. Consolidated framework of public-policy responsibilities

\begin{tabular}{|c|c|c|c|c|c|c|c|c|c|c|c|}
\hline \multirow[b]{2}{*}{$\begin{array}{l}\text { Values and } \\
\text { objectites }\end{array}$} & \multicolumn{11}{|c|}{ Actions } \\
\hline & $\begin{array}{l}\text { Research } \\
\& \\
\text { derelop- } \\
\text { ment }\end{array}$ & $\begin{array}{l}\text { Systemi } \\
\text { retiability }\end{array}$ & $\begin{array}{l}\text { Portfoliofisk } \\
\text { management }\end{array}$ & DSM & $\begin{array}{c}\text { Non- } \\
\text { discriminatory } \\
\text { transmission } \\
\text { access }\end{array}$ & $\begin{array}{l}\text { Low- } \\
\text { income } \\
\text { programs }\end{array}$ & $\begin{array}{l}\text { Minimum } \\
\text { sernice } \\
\text { standards }\end{array}$ & $\begin{array}{l}\text { Consumer } \\
\text { provection }\end{array}$ & $\begin{array}{l}\text { Fair treatment } \\
\text { of stranded } \\
\text { commitments }\end{array}$ & $\begin{array}{l}\text { Renewwable } \\
\text { energy }\end{array}$ & $\begin{array}{l}\text { Poilution } \\
\text { reduction }\end{array}$ \\
\hline \multicolumn{12}{|l|}{ Economic progress } \\
\hline $\begin{array}{l}\text { Industrial } \\
\text { competitiveness }\end{array}$ & $r$ & $\checkmark$ & $\checkmark$ & $\checkmark$ & $\checkmark$ & & & & & $\checkmark$ & $\gamma$ \\
\hline $\begin{array}{l}\text { Exonomic } \\
\text { dexelopmintl }\end{array}$ & $\checkmark$ & $\checkmark$ & $\checkmark$ & $\checkmark$ & $\checkmark$ & & & & & $\checkmark$ & $\checkmark$ \\
\hline Customer choice & $\checkmark$ & $\checkmark$ & & $\checkmark$ & & & $r$ & & & $\checkmark$ & \\
\hline Public participation & & & $\checkmark$ & $\checkmark$ & & & & $\checkmark$ & $\checkmark$ & & \\
\hline $\begin{array}{l}\text { Fair-trade } \\
\text { safeguards }\end{array}$ & & & & & $\checkmark$ & & & $\checkmark$ & & & \\
\hline $\begin{array}{l}\text { Prolection of human } \\
\text { welfare }\end{array}$ & $\checkmark$ & & $\checkmark$ & & & $\checkmark$ & $\checkmark$ & $\checkmark$ & & & $\checkmark$ \\
\hline \multicolumn{12}{|c|}{ Environmental stewardshıp } \\
\hline $\begin{array}{l}\text { Clean electricity } \\
\text { generation and } \\
\text { deliven }\end{array}$ & $\checkmark$ & & $\checkmark$ & $\checkmark$ & $\checkmark$ & & & & $\checkmark$ & $\checkmark$ & $\gamma$ \\
\hline $\begin{array}{l}\text { Regional } \\
\text { environmental } \\
\text { qqualiț: }\end{array}$ & $\sigma$ & & & $\checkmark$ & & & & & & $\checkmark$ & $\checkmark$ \\
\hline
\end{tabular}


Two important concerns are not indicaled in Table 2. One relates to time. Satisfying values and objectives is a continuing process. Satisfaction of values, the athainment of objectives, and implementation of the associated actions require sound long-ferm decisions. Making longterm decisions is always difficult. Such decisions are even more complicated given the many risks and uncertainties about the future structure of the electricity industry, costs and performance of different electricity-production and -consumption technologies, costs and availabitities of different fuels, federal and state political preferences, and environmental restrictions (e.g., limits on etmissions of carbon dioxide and other greenhouse gases). Second, assessing and balancing costs and benefits over time and in the face of risk and uncertainty can be extraordinarily difficult given the interselated nature of values, objectives, and actions.

\section{COSTS OF MEETING RESPONSIBLITIES}

Table 3 and Fig. I show how much money utilities now spend on various public-policy actions. To provide some context, U.S. electricity revenues totaled \$185 billion in 1992 [Energy Information Administration (EIA) 1993]. The Natural Resources Defense Council estimated that California's investor-owned utilities (IOUs) spent less than $6 \%$ of total revenues on R\&D, lowincorne prograns, and DSM programs in 1993 and 1994 (Demand-Side Report 1995).

Estimating the costs of some functions may not be possible because a reasonable baseline does not exist. For example, the cost to maintain system reliability could, in principie, be measured (e.g., based on the savings associated with fewer generating and transmission reserves) if we had a reference system with specified lower levels of reliability. Although we searched diligently, we were unable to find estimates of the incremental capital and operating costs of utility renewable resources. Finally, the costs shown in Table 3 and Fig. I ignore the benefits derived from these public-policy actions. Presumably, the benefits outweigh the costs

These numbers provide only the barest outline of how much money is beng spent by utilities on public-policy actions. However, they may be of value because, as Table 3 indicates, estimates of spending on specific objectives are not widely reported.

The largest expenditures are for pollution control, foliowed by DSM, R\&D, and lowincome programs (Fig. 1). The estimate for fair treatment of stranded assets refers to the magnitude of the problem, not what utility shareholders, customers, and governments have spent or lost to date. Data are not generally available to estimate costs associated with system reliability and portfolio/risk management (e.g., fuel diversity), although efforts to unbundle utility costs will eventually allow such estimates to be made.

*Nanhydro renewables (primarily geothermul) accounsed for $0.3 \%$ of U.S. generation in I993 (EIA 1994). If the incremental cost of this generation was If/kWh, then utilities spent $\$ 96$ million on renewables. 
Table 3. Estimates of electric-utility expenditures on public-policy actions

\begin{tabular}{ll}
\hline Public-policy actions & \multicolumn{1}{c}{ Estimated expenditures } \\
\hline $\begin{array}{c}\text { Nondiscriminatory } \\
\text { transmission access }\end{array}$ & No data \\
$\begin{array}{c}\text { Fair treatment of } \\
\text { stranded } \\
\text { commitments }\end{array}$ & $\$ 69$ to 99 billion potential loss (Baxter and Hirst, 1995) \\
$\begin{array}{c}\text { Minimum-service } \\
\text { standards }\end{array}$ & No data \\
Pollution reduction & 1992 JOU investments in environmental-protection facilities \$58 \\
& $\begin{array}{l}\text { billion (EIA 1993); 1992 lOU operating expenses for } \\
\text { environmental protection \$3 billion }\end{array}$ \\
Portfolio/risk & No data \\
management & No data \\
Renewable energy & 1993 IOUs, \$615 million (FERC Form-1); 1993 Electric Power \\
R\&D & Research Institute budget, \$560 million \\
System reliability & No data \\
DSM & 1993 \$2.8 billion (Hadley and Hirst 1995) \\
Low-income & 1992 all utility low-income energy-efficiency programs, \$141 \\
programs & million (Brown et al. 1994); \\
& 1992 uncollectible accounts, \$665 million, of which $\sim 5 \%$ was \\
related to low-income customers (EIA 1993)
\end{tabular}


\% OF ELECTRIC REVENUES

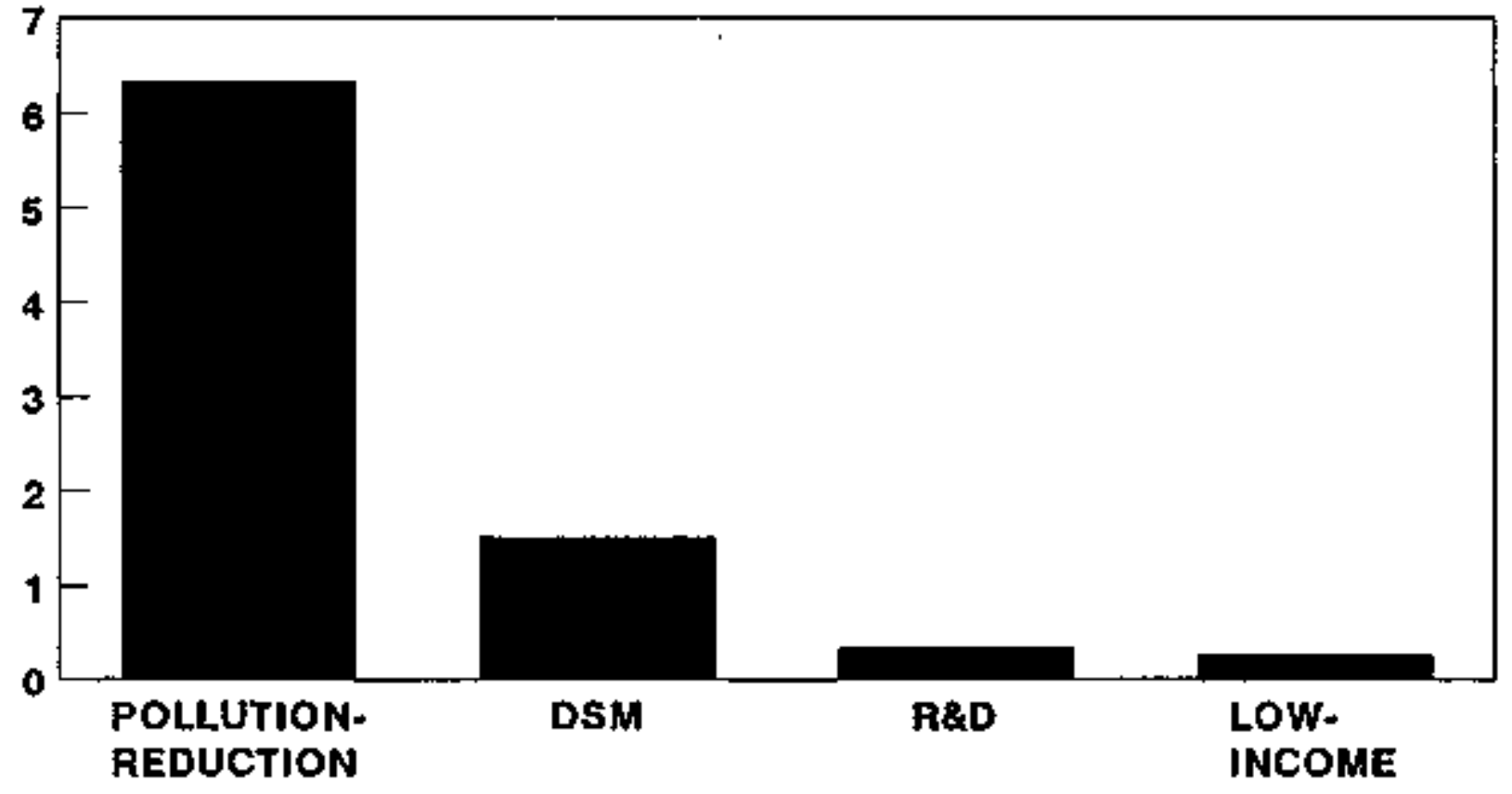

Fig. 1. Partial compilation of electric-utility costs for some public-policy functions. 



\section{ROLE OF MARKETS}

This section examines the strengths and limitations of competitive-market institutions vis a vis meeting the values, objectives, and actions presented above. Thus, the question addressed here is what objectives and actions might a competitive-market-based industry achieve with only limited regulatory oversight. To help answer this question, we offer four general criteria to understand market failure and other problems in achieving the actions listed in Table 2 . We focus on a retail-wheeling indusiry structure because such a structure poses the greatest challenge to achieving public-policy functions. Using these criteria and this industry stucture, we assess which actions may be at risk in a market-based electric industry.

\section{MARKET STRENGTHS}

Many U.S. industries have been substantially deregulated, including the trucking, natural-gas, airline, and long-distance telephone industries. The electric-utility industries in the United Kingdom, Norway, Australia, and Eastern Europe have also undergone major changes. In addition, capitalism is gaining momentum worldwide and represents one of the most powerful trends affecting the U.S. and international commerce (Schwartz 1991). It is no surprise that the U.S. electric industry is now facing substantial changes.

The benefits of relatively unfettered, competitive markets to society in general and consumers in particular can be substantial. In markets, buyers and sellers are free to negotiate the prices and sales of goods and services. In a perfectly competitive market, prices equal marginal costs, which maximizes economic efficiency and consumer surplus. Competition among sellers tesults in several beneficial outcomes: increased efficiencies, which lower prices; increased attention to product and service quality to differentiate products and services from those of competing firms; better customer service; elimination of subsidies for special groups of customers; and imnovation in goods and services. Communications among buyers and sellers also result in an exchange of information about preferences and cost structures, respectively. Through price signals, markets can quickly adjust to changes in preferences and to changes in production functions. Market institutions are also better at responding to global competition than are regulated industries.

Ideally, competitive electricity markets could provide the benefits mentioned above Buyers and sellers of electricity will be able to exchange information more direclly, efficiencies in electricity generation and delivery will increase, consumer choices will increase, and innovation will be spurred. Deregulation of the electric industry may also foster economies of scale through mergers and acquisitions and economies of scope through investments in complementary industries, such as energy services and telecommunications. Deregulation witl 
also allow individual buyers and sellers to apply their own risk preferences and make their own investment decisions instead of being held captive to PUC decisions.

\section{MARKET LIMITATIONS}

Although competitive markets offer many benefits, they do not always operate in a textbook fashion. Market failures represent substantial misallocations of resources that stem from apparently intractable features of certain markets. Market failures include: (1) externalities, which are benefits or costs resulting from but not solely borne by participants in a particular transaction; (2) imperfect information, which represents incomplete or differential levels of knowledge by participants in a transaction; and (3) public goods, whose benefits cannot be captured adequately by individual participants in markets.

Because the production and transmission of electricity create environmental problems (e.g, acid rain, global warming, and electromagnetic fields), extemalities are an important market failure associated with electricity. Markets may not produce enough information on, for example, energy-efficiency choices, if the information becomes readily available free of charge. In such a case, the producing firm would not be able to earn enough money to justify collection, analysis, and dissemination of the information, leading to a public-goods problem.

Other reasons also keep markets from achieving certain objectives. Problems that limit competition include: monopoly based on economies of scale; monopoly based on short-term constraints to change; monopsony; seller misrepresentation; restraint of trade; discriminatory pricing; constraints on communications about product attributes; and artificial market altocation and production limitation. Here are several other reasons why markets could fail to achieve an action:

- Firms may decline to participate in markets for certain goods and services because of limited market sizes and profit potential. This is a problem in attracting retailers to lowincome urban areas, for example.

- Firms may not produce goods and services based on difficult-to-protect intellectual property because competitors who steal the intellectual secrets do not need to invest in the R\&D and can offer lower prices.

- Markets may not materialize because firms may find it difficult to attract R\&D and investment capital for product development and facility construction, respectively.

- Firms may not adopt an action because the associated expenditures and results are not seen as central to the firm's success (e.g, reducing emissions of pollutants below required levels).

- Some regions may have insufficient human capital (e.g.s well-trained mechanics) to develop products and manage sophisticated, technological businesses. 
- In some markets, firms may be able to produce functional products but find that the associated transaction costs are too high. For energy-efficiency markets, the cost to save a residential-sector $\mathrm{kWh}$ is much higher than the cost to save a commercial-sector $\mathrm{kWh}$.

- In some markets, firms may be able to produce functional products but find that associated liability (insurance) costs are too high. Examples include the small-aircraft and football-helmet industries and potential environmental liabilities associated with redeveloping urban industrial areas.

- Firms may be able to produce only proxies of the action determined necessary to achieve certain objectives. For example, firms do engage in strategic planning and decision making under uncertainty. However, their decisions may not coincide with societal interests with respect to portfolio/risk management. In particular, private-sector discount rates may be higher than societal discount rates, leading to substantial differences in long. term investment decisions.

The action in question may simply not be a good or service that can be bought and sold in the marketplace. Examples include fair-trade safeguards; justice; and protection against discrimination based on race, sex, and ethnicity.

- U.S. firms sometimes complain that foreign countries do no1 honor U.S. patents. copyrights, and trademarks. Also, environmental problems are becoming international in scope, and several are directly fied to the electric industry, especially acid rain and global warming. R\&D on new renewable, pollution-reduction, energy-efficiency, and other technologies could have international trade implications. Lastly, imposition of environmental and worker-safety regulations, while helping to achieve other social goals, can raise product prices, which may affect global competitiveness and trade flows.

\section{FUTURE ELECTRIC-INDUSTRY STRUCTURES}

During the past few years, many entities and individuals have suggested alternative structures for a more competitive electricity industry, sec, as examples, the many proposals offered in response to the California PUC (1994) "blue book" and those presented in recent issues of The Electricity Joumal. These proposals differ both in the length of the transition period to a new structure and in the final structure itself. Some proposals call for almost immediate changes that would allow all retail customers to select their electricity suppliers. Others allow gradual increases in retail competition, with full retail wheeling occurring ten or more years from now. Some focus on wholesale competition, with retail customers continuing to be served by retail-monopoly-franchise utilities.

Some proposals call for today's utilities to deintegrate; that is, to divest themselves of their generation, transmission, and/or distribution assets. Some proposals call for an independent system operator who will, on a second-to-second basis, control the transmission network and enough generation capacity to maintain system stability and integrity. Other proposals would 
expand the role of the system operator to include the creation of a spot market for electricity, with prices that varied every hour in response to changes in customer demand and in generator offers.

For purposes of discussing public-policy responsibilities, the existence of retail wheeling is critical. If only wholesale wheeling were allowed in a restructured industry, the local distribution utilities would still hold retail-monopoly franchises and remain fully regulated by PUCs. These distribution utilities could, in principle at least, continue to carry out the publicpolicy functions that today's vertically integrated utilities do. On the other hand, if retail wheeling is allowed or encouraged, state and federal regulators (as well as legislatures) may need to identify new mechanisms for meeting these societal functions. Because maintaining these societal functions will pose new challenges in an industry with full retail wheeling, we focus on such a scenario.

Figure 2 shows one such possible industry structure. The industry, in this scentario, consists of six separate entities. Three of these entities - generating companies, marketers and brokers, and customer-service companies-are competitive and largely unregulated. Three of these entities-system operation, transmission, and distribution-are monopolies and would continue to be regulated. Under such a scenario:

- A variety of independent power producers would build and operate power plants, subject only to siting and environmental regulations. That is, investors rather than govemnents would decide on the sizes, types, locations, and timing of new generating units. The output from these units would be sold through a variety of contracts (either directly to end-use customers or through marketers and brokers) or on the spot market.

- The system operator would be responsible for matching generation to customer loads, given the constraints of the transmission network. The system operator would meet all the control-area requirements as specified by the North American Electric Reliability Council. As defined here, the system operator would own no generating units and no transmission facilities.

- The transmission company would own and maintain transmission lines, substations, and other transmission-network components. Similarly, the distribution company would own and maintain local distribution systems.

- The system operator and transmission companies would be regulated by FERC because their focus is on wholesale markets. State PUCs, on the other hand, would regulate local distribution companies. 


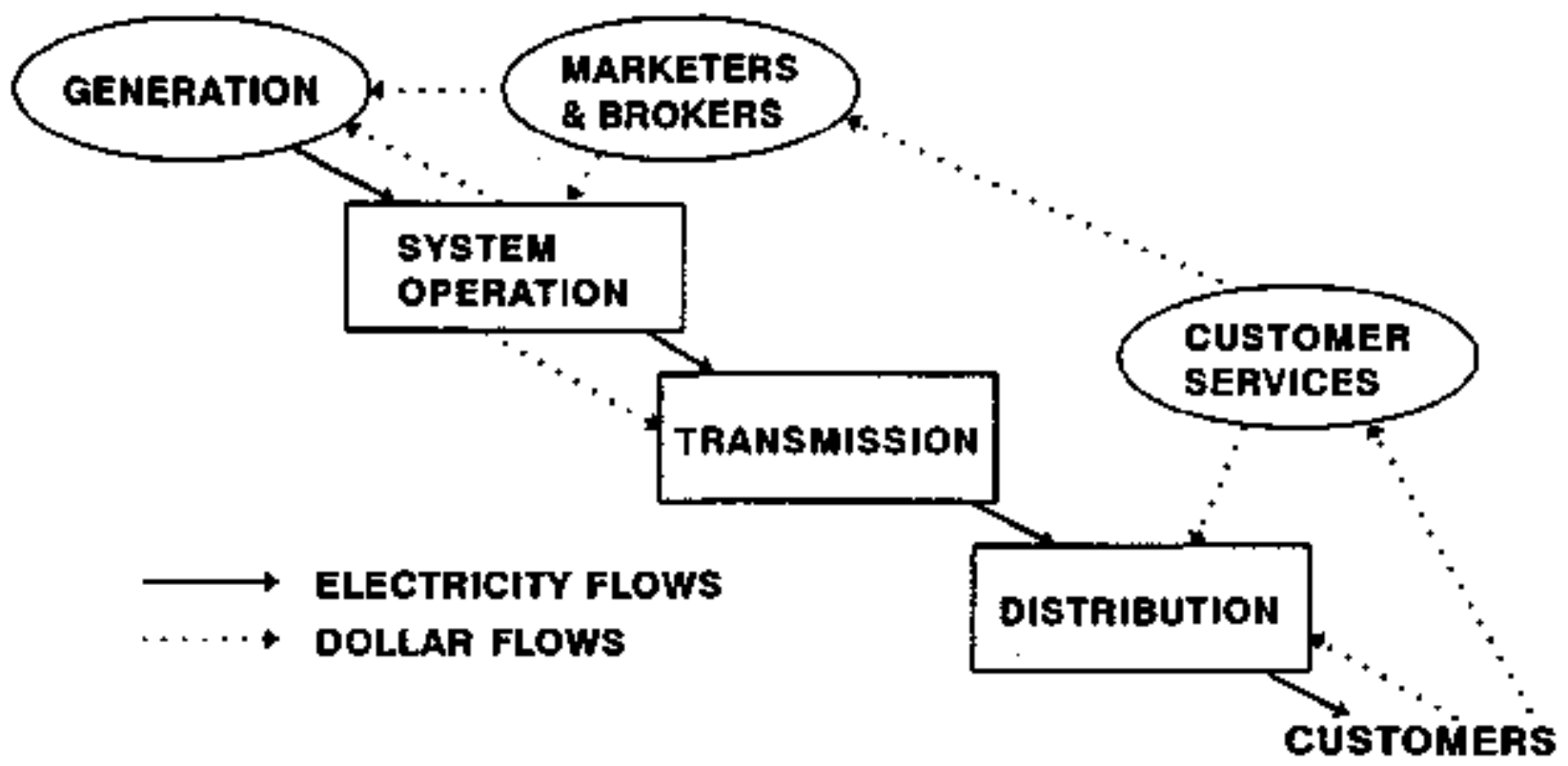

Fig. 2. Possible future structure of the U.S. efectricity industry with foll retail wheeling. The oval functions are competitive, and the rectangutar ones are regulated monepolies.

- Marketers and brokers would arrange financial and perhaps physical trades of electrictiy between generating companies and custamers. Similarly, customer-service companies would offer metering, billing, information, and other services, such as energy efficiency and load management. Because these entities, like the generating companies, would be operating in competitive markets, they would be only lightly regulated. For example, PUCs might impose minimum service standards on all companies that sell electricity at retail. But PUCs would not conduct rate cases and would not set tariffs for different customer classes. Thus, PUC oversight of these companies would be much less than PUC regulation of today's utilities.

Competition at the wholesale level will force generators to lower operating costs. They will lower costs by putting pressure on fuel suppliers, by increasing operating efficiencies (e.g., by lowering heat rates), by improving plant availability, and by cutting labor costs. These positive changes assume that there are enough generating entities that none has market power.

An industry characterized by retail wheeling will likely lead to economic progress, with increasing economic efficiency and industrial competitiveness. Markets will likely spur innovation of new electricity services and pricing options. Markets will allow different people to pursue activities that entail different levels of risk, in place of a regulated approach that implements a plan that reflects only one level of risk imposed on all customers. 


\section{MAPPING MARKETS ONTO RESPONSIBILITIES}

If industry restructoring proceeds as suggested above (Fig. 2), how will that affect the various public-policy functions discussed here? Specifically, this form of restructuring could reduce the ability of states, through PUC mandates and other traditional regulatory levers, to implement portfolio/risk management and to collect revenues through bundled utility tariffs to pay for and deliver services through utility programs, which include R\&D, DSM, low-income programs, renewable-energy use, minimum service standards, and pollution reduction. In addition, electricity systems that had been designed, built, operated, and maintained by one entity, the utility, now would be created from the decisions and actions of many parties, which could affect system reliability. Retail competition may increase the need for consurner protections. Finally, negotiating a transition to this new industry structure would require assurance of nondiscriminatory transmission access and fair treatment of stranded commitments.

Thus, moving to retail competition means that many of the actions Jisted in Table 2 may need to be achieved in a new manner. More fundamentally, the private and public sectors may need to identify new actions (the columns in Table 2) to achieve the underlying objectives (the rows in Table 2). Two actions need to be achieved to reach retall competition, nondiscriminatory transmission access and fair treatment of stranded commitments. Consumer protection may need to receive more emphasis in a retail world.

The discussion below considers what actions are likely to be achieved through market institutions. The public-policy actions are grouped into three categories, those that in an industry characterized by retail competition will tikely: (1) be achieved by markets; (2) be partialty achieved by markets; and (3) not be achieved by markets.

Actions Likely to be Achieved by Markets

System reliability: If the system operator is able to maintain control over the independent generators and the transmission grid, in accordance with North American Electric Reliability Council procedures, system reliability should remain unchanged. Presumably, FERC will oversee the behavior of the system operator and the transmission entities, as well as wholesale transactions in general, to ensure this result Creation of RTGs and implementation of openaccess, comparable transmission tariffs should hejp in this regard. Finally, competitive markets will allow consumers to trade off the reliability of the service they receive and the price of electricity they pay. FERC may need to pay more attention to system reliability than it needed to in the past because of the likely substantial increase in number of entities whose actions could affect system reliability. FERC and others may also need to devote considerable effort to defining and distinguishing between system reliability and the levels of reliability that individual customers can select for their own service.

Nondiscriminatory transmission access: Because transmission is a monopoly, it will remain under FERC regulation. Discrimination could be a concern if transmıssion owners and operators also own generation or sell electricity to retail customers (Lewis and Besser 1995). A standalone 
transmission entity, on the other hand, would bave no incentive to discriminate among generators or customers. In part to address these concerns, FERC (1995) issued a Notice of Proposed Rule Making that offers a regulatory approach to ensure open transmission access with "comparable" tariffs. If the industry deintegrates as outlined above (Fig. 2), then transmission access is unlikely to be a problem; otherwise continuing FERC oversight may be necessary.

\section{Actions Likely to be Partially Achieved by Markets}

Research and development: The electric industry will spend money on R\&D. The questions are how much money and on what projects. Recent cutbacks in R\&D spending by the Califomia utilities and reductions in utility support for the Electric Power Research Institute suggest that a competitive industry may cut R\&D spending. Some people are concerned that the industry will coast on its past $R$ \&D investments and current knowledge at the risk of being overtaken by international competitors. Probably, R\&D related to public concerns, such as electromagnetic fields and global warming, will receive much less support than in the past because these expenses are not central to the success of most players in a retail world. The industry will likely not undertake the level of basic, long-term, high-risk research needed to realize qualitative technological change in the industry. On the other hand, the applied research undertaken in this scenario is tikely to be sharply focused on real industry problems and, therefore, is likely to yield solutions that are implemented, that lower costs, and that increase consumer choices

The Califomia PUC (1995) wrote: "In a more competitive market, individual fitms will have a vested interest in pursuing research which improves their strategic position. ... This proposal allows continued ratepayer funding for research that is related to continuing monopoly functions, but not other competitive interests. In anticipation of full competition in the generation sector, the research functions of the utility should be reduced and tailored to support regulated functions. Research that bas tradilionally been conducted by utilities and which serves a broader public interest (public goods research), should not be lost in the transition to a more competitive environment."

Demand-side management: Customer-service entities will surely offer, for profit, various energy-efficiency and load-management options to their customers (Newcomb 1994). These programs will likely focus on customer service rather than on DSM as an energy and capacity resource. [In the language of the tests for DSM cost-effectiveness, program decisions will be based primarily on the rate-impact measure rather than the total-resource-cost test (Hirst 1994).] Thus, a key policy issue concerns the extent to which such profit- and customer-driven programs will achieve the energy, capacity, and environmental-quality objectives of today's DSM programs. On the other hand, driven by the pressure to eam money, companies will continually innovate as they search for products and services that meet customer needs and for methods to market successfully to customers. Thus, the programs that succeed are likely to meet customer needs and to do so in a way that does not burden other customers. (Today's utility DSM programs are, in general, paid for in part by all customers, not just those who participate in the programs.) In general, retail competition in which many customers face real-time pricing will strongly pronote cost-effective load management, but may do little to promote overall energy 
efficiency. Governments may need to identify other ways to provide the environmental benefits of DSM aimed at energy efficiency.

Renewable energy: The loss of integrated resource planning in a retail-wheeling world, and thus the ability to engage in societal portfolio/risk management (see below), may reduce use of renewable resources whose cosis are above today's market prices. Possible reductions in R\&D funding may delay the time when renewables are cost-competitive with other supply options. Elimination of regulatory incentives for renewables, such as renewable setasides, could also delay the time when renewables are cost effective. On the other hand, if access to transmission facilities and to customers is truly nondiscriminatory, renewable resources will have the same access to markets that all other supply resources have. If consumers want to purchase "green" electricity, the competitive marketers, brokers, and customer-service companıes will obtain renewables and other environmentally benign electricity resources. Also, those customers that want to diversify their resource portfolio (e.g., to hedge against possible increases in natural gas prices) may choose to buy renewables. Because of these countervailing forces, we have no basis now to estimate the magnitude or timing of the future demand for tenewable resources. As with energy efficiency, governments may have to seek other actions to provide the environmentalquality objectives that renewables today provide.

Eair treatment of stranded commitments: This issue often dominates discussions of utility restructuring. The fact that utility stocks have decreased in value all over the country, some as much as $30 \%$ or more, indicates that the financial market is worried that utility shareholders will suffer substantial losses. FERC (1995) recently committed itself to utility recovery of all "legitimate and verifiable stranded costs" at wholesale. Increasingly, state PUCs are making similar commitments that utility shareholders will not be unfairly burdened by stranded commitments. Ultimately, regulators, perhaps more than markets, will decide on appropriate allocations of these costs among utility shareholders, different customer classes, and taxpayers.

Portfolio/risk management: People, depending on their beliefs about governments and markets, hold very different views about the ability of producers and customers to make rational longterm decisions. Market proponents believe that market participants should be free to make their own decisions based on individual perceptions of risk and discount rates. They believe that such decisions will also be societally optimal. Those who favor government oversight believe that markets acting alone will focus too narrowly on short-term considerations (i.e., that private decision makers use discount rates that are too high). Ultimately, the issue concerns the relative merits of having PUCs make decisions about the types and timing of resource acquisitions with the risks of those decisions borne by all customers vs investors in generating units and customers making individual decisions and bearing only the risks associated with their decisions. With respect to public policy, even if markets make long-term decisions, such decisions will have a different focus and value base from decisions made by agents of the public interest. Market decision making is not inclusive, not prone to balancing the allocation of costs and benefits among those with and without market power, and not inclined towards environmental stewardship and protection of future generations. Low-probability, catastrophic-consequence events that have nationd or intemational effects are not handled well by market decision making. 
Ultimately, the issue is whether market power or political power should dominate such decisions.

Actions Likely Not to be Achieved by Markets

Bollution-reduction methods: Industry has begun to internalize the concept that pollution indicates an inefficient production process. This maxim applies more strongly to manufacturing processes than to the production of electricity. Especially with respect to air-pollution-control technologies, these costs will continue to be seen as not central to the profitability of generation firms, and thus will not be undertaken naturally. On the other hand, if regulators can establish clear incentives to reduce emissions (e.g., the $\mathrm{SO}_{2}$-emissions trading allowed under the 1990 Clean Air Act Amendments), industry will find economically efficient ways to comply. Environmental dispatch of power plants is one such example. In this approach, regulators would "tax" certain pollutants or establish ceilings on total emissions, as with the $\mathrm{SO}_{2}$ limits. In such a situation, generators would sell the output from their units on the basis of the sum of direct operating costs (i.e., fuel plus operating and maintenance costs) plus emissions cost (as reflected by the market price for a ton of pollutant).

Low-income programs: Providing special services to low-income households is often not profitable. Thus, private firms will likely not maintain such programs However, to the extent that competition lowers electricity prices for all consumers, low-income consumers will benefit. And if suppliers offer customers a range of services, including a tradeoff between reliability and price, low-income consumers may choose lower teliability in exchange for even lower prices. Thus, although competitive markets are unlikely to offer special programs for low-income customers, the drive to cut costs and increase options may benefit low-income customers as well as other customers. The California PUC (1995) expressed its preference that, in the long term, "existing state agencies or private entities" assume the low-income responsibilities that the vertically integrated utility has in the past. Such changes would require legislative, as well as PUC, changes.

Minimum service standards: Minimum service standards, such as those related to meter accuracy and limits on the termination of services (e.g., in the winter, to prevent deaths from freezing), are not a natural feature of markets. If desired, they will need to be government mandated.

Consumer protection: This public-policy action is not a natural feature of markets. This issue will grow in importance as electricity consumers are exposed to a plethora of unregulated electricity brokers and service providers.

Not surprisingly, objectives associated with social equity are not in the purview of the market. In a retail-competition world, new mechanisms to raise revenue for and deliver socialequity programs will be needed.

In addition, private firms will not adopt environmental-protection actions that do not improve profitability (e.g., by increasing product quality or reducing waste-disposal costs). As 
indicated above, the magnitude of market-induced spending on energy efficiency, DSM, R\&D, and renewables is uncertain. Overall, it seems that environmental stewardship could be a stranded benefit in a retail-competition structure, absent new government actions. 


\section{ROLE OF GOVERNMENTS}

Governments will continue to play a role in the electric industry. This is especially true with respect to the values, objectives, and actions associated with social equity and environmental stewardship. In general, governments have achieved sorne success at providing public goods, such as defense and transportation infrastructure, enforcing laws that regulate human behavior, mediating and coordinating human behavior (e.g., through the justice system, standard setting, and goverment operation of the air-traffic control system), and providing collective services, such as education and health care. Governments also help shape ane's identity, for we often describe ourselves according to our political jurisdiction (e.g., U.S. citizen).

Govemunents, just like markets, have strengths and weaknesses. We present four tests to help make judgments about govemments' abilities to achieve specific types of public-policy actions. We also list mechanisms that governments can use to achieve such actions. Finally, we assess these mechanisms using the four tests as a basis.

\section{CRTIERIA FOR EVALUATTNG GOVERNMENT RESPONSES}

Ability to Describe the Action

The action, or services and products associated with the action, must be clearly describable. If this test cannot be met, then the government will not have a clear mission or direction. Garbage collection is an example of a clearly describable service. With respect to the electric industry. governments have been successful in overseeing well-understood energy-efficiency services to residential customers (e.g., number of homes audited and MWh saved each year).

Public Support for the Activity

Governments will have more success at achieving actions that receive a high level of public support. If the public supports an action, if it is vital that the action be accomplished (e.g., within a short time), and if the government can mobilize resources to achieve the action, then government is an appropriate means to achieve the end. For example, immunization against contagious diseases is an activity that has high public support, must be accomplished, and can be achieved. Protecting people's health during acute weather events through programs such as winter moratoria is an electric-indusiry action that receives high public support and is essential to accomplish at the time of the event.

\section{Cultural Association of the Action with Government}

Citizens must agree that government not only has a responsibility for achieving the action but also that the govemament itself is an appropriate provider of the particular service or product. 
Theoretical considerations pale when compared to popular sentiment on this particular test. Garbage collection is an interesting case because, over time, popular sentiment has changed from expecting government to provide the service to believing that the private sector can most efficiently provide the service. This sentiment is fundamental to the debate about deregulating the electricity industry.

Ability of Government to Achieve Actions

The bottom-line question is whether a government program or other government actions can be implemented in a reasonable fashion and at reasonable cost to provide the service or product. Efficiency is not the only consideration. If the action is extremely important, must be achieved, and can be provided only by the government, some inefficiencies will be tolerated. For example, a fair and functioning justice system is an extremely important public-policy action, and only the government can be entrusted with the justice system. Although there is widespread agreement that the current system is inefficient, no one seriously proposes to eliminate the system or to transfer it to the private sector.

\section{POTENTIAL ENABLING MECHANISMS}

Governments have essentially three types of mechanisms to use to achieve public-policy goals: (1) raise taxes and use tax incentives; (2) impose regulations; and (3) supply the services themselves or through proxies. In general, the tax mechanisms can be used to fund public-policy programs and to influence electricity use to meet values and objectives, such as environmental stewardship. Several mechanisms representing each type are listed betow.

Taxes and Tax Incentives

Distribution charke: A non-bypassable charge applied at the point of consumption of electricity (California PUC Working Group 1995). The charge could be fixed (\$/month) or usage-based $(\$ / k W$ or $\phi / k W h)$.

Uplift charge: A fee added to electricity at the wholesale level. In the United Kingdom, the uplift charge includes various ancillary services provided by the system operator. If FERC approved such charges, they could be imposed at the wholesale (transmission) level and would apply throughout a particular control area. This charge is the transmission equivalent (subject to federal oversight) of the distribution charge (subject to state oversight).

National wires charge: At the national level, a charge could be placed upon all transmission within FERC's purview. This is equivalent to an uplif charge with the amount set uniformly throughout the country. For a precedent, the Federal Communications Commission authorizes a charge to all long distance customers to support matching-grant programs with local phone companies to guarantee universal service. This is an annual \$l billion program.

Energy charge: This charge is levied against all forms of energy to implement broad energy policies. For example, Vermont has a $0.5 \%$ sales tax, paid by the seller, on all retail energy sales. The money is placed in a weatherization trust fund. 
Emissions fees: This tax would be applied on fuels in proportion to their emissions of certain pollutants (e.g, in terms of \$/ton of $\mathrm{CO}_{2}$ or per ton of $\mathrm{NO}_{x}$ ). Emissions fees are similar to energy charges, but they are focused on reducing the environmental damages associated with electricity production.

General taxes: Revenue for public-policy actions can be collected through income taxes, sales taxes, or property taxes.

Taxcredits: Governments can use tax credits to encourage certain behaviors. The 1992 Energy Policy Act provides a $1.5 \mathrm{k} / \mathrm{kWh}$ incentive for wind energy. During the $1980 \mathrm{~s}$, the federal and several state tax codes provided incentives for residential retrofit. Of course, these credits require a revenue source.

\section{Regulatory Levers}

Bertfolio standard: "As a condition of doing business in a state, every power supplier ... would be required to purchase a percentage of its energy needs from renewable resources. The percentage would be determined by the state based on its resource diversify, environmental protection, economic development goals and other factors" (American Wind Energy Association 1995). Portfolio standards could also apply to DSM and any other resources deemed to be in the public interest.

Govemment created markets: Governments can create markets to further social goals. To create a market, the government creates "goods" to buy and sell, determines the initial allocations of the good, and sets rules to govern market transactions. For example, under the federal Clean Air Act Amendments, the government created a market for $\mathrm{SO}_{2}$-emission credits.

Emission caps: Govemments could limit emissions of pollutants to prespecified levels at the level of power pools or other regional generation entities. Emission allowances could be traded within and among power pools.

Retail licenses: Organizations selling electricity to consumers would be required to have a license and pay certain fees for the privilege. PUC oversight would be required.

Green electron wheeling: State regulators would allow retail wheeling only for electricity generated by environmentally benign resources.

Biddable franchises: Geographic regions would be organized into franchise areas, and bidding processes would be established, under state standards, to award contracts to supply power to the franchises.

Perfomance-based regulation: A method for basing utility revenue on achievement of specific performance standards (Joskow and Schmalensee 1986). Performance requirements could be tied to public-policy actions, such as DSM and renewables. PUCs would oversee such regulations for distribution utilities, and FERC would oversee such regulations for transmission utilities. 
Eederal transmission-access regulations: FERC issues regulations that affect transmission access, pricing, and expansion. The March 1995 proposed rule, for example, emphasizes open access and comparable service in which the transmission owner provides transmission services to others at the same prices and terms as it provides those services to itself.

Euvironmental-protection regulations: Govenments regulate emissions of hamful substances into the environment through laws such as the Clean Air Act, the Clean Water Act, and the Resource Conservation and Recovery Act.

Power-plant siting and certification: State environmental-protection agencies se1 standards for construction and operation of new generating facilities related to water quality, air quality, and land use. All generators would be required to meet these requirements.

Energy-efficiency standards: The U.S. Department of Energy sets minimum energy-efficiency performance standards for a variety of residential and commercial appliances and equipment. State and local government set similar standards for construction of new residential and commercial buildings. The 1992 Energy Policy Act strengthened both federal appliance efficiency standards and state building codes.

Program-Delivery Mechanisms

Tnust funds: Trust funds represent a combination of tax-collection and government-delivery mechanism. As examples, the federal government operates trust funds for highway constructoon and air-traffic control. In Vermont, energy tax revenues are placed in a trust fund for low- income weatherization.

Government-managed long-term R\&D: The federal government, through the Department of Energy and its national laboratories, can continue to fund, manage, and conduct long-term R\&D on electricity generation, transmission, distribution, end-use efficiency, program delivery, and related policy issues. In addition, the federal government, in conjunction with private-sector parthers, can fund and manage programs to demonstrate new technologies in real-world settings.

National nonprofit R\&D center: Revenue collected by the federal government and/or the states could be used to support independent, nonprofit R\&D centers. The Gas Research Institute, which is funded by a national charge on natural gas set by FERC, is one example of this concept.

Govermment low-income programs: Governments (e.g., local community-action agencies and state departments of community services), instead of utilities, could expand their operation of lowincome programs, such as weatherization.

Nonprofit organizations: Independent organizations could promote energy efficiency and renewables, and provide low-income services. They could be funded directly by government or be supported by trust funds or by industry.

State integrated resource plans (IRPs): PUCs, state energy offices, and state environmental agencies could develop state-level integrated resource plans (New York Energy Planning Board 
1994). These plans could form the basis for state approval of energy-facility siting decisions and would inform the electricity industry and citizens about the state's preferences for a long-term energy-resource strategy. The IRP could also be used to help set levels of various charges, direct social-equity programs, and modify regulatory mechanisms.

Begional transmission groups: Under FERC sponsorship, RTGs are being formed to coordinate fransmission access, pricing, and planning. RTGs could expand their roles to include overall resource planning, to oversee system reliability (much as the regional reliability councils do today), and act as the collector of revenue (e.g., through up-lift charges) for programs supporting social equity and environmental stewardship.

Interstate compacts: States could enter into agreements to manage certain aspects of the electricity system (e.g., the siting of new generation and transmission facilities, and imposition of taxes). The U.S. Congress must approve interstate compacts. Interstate compacts could help to handle multijurisdictional environmental problems.

Joint State Boards: FERC could establish such boards to address issues that cross jurisdictional lines, such as transmission access.

Advocates: Government could appoint and fund offices to represent various interests on electricity issues. State-funded consumer advocates now operate in about forty states. Informal (unofficial) advocates also exist, who act to protect the environment and the interests of low-income households. Difficult questions surround who appoints and funds advocates and what issues deserve theit attention.

Information programs: Government agencies have a long history of providing information to the public. The U.S. Department of Energy and state energy offices offer information and advice to consumers and producers about energy-efficiency opportunities, how to deploy renewable-energy resources, and other energy topics.

Government purchase programs: Governments could help achieve objectives by using their enormous purchasing power to change markets for energy-efficient goods and services. For example, the federal govemment buys $\$ 10$ to $\$ 20$ billion a year on energy-related products (Harris et al. 1994). Also, government agencies, such as military bases, could purchase electricity portfolios that exceed some prespecified percentage of renewables.

Eneroy-efficient mortgages: Govemments could subsidize interest rates granted on mortgages of energy-efficient homes or could tax interest paid on energy-inefficient homes.

\section{GOVERNMENT IMPLEMENTATION}

This section discusses how difficult in might be for govemment to implement the types of mecharisms listed above. In this context, difficulty is defined to connote technical barriers to implementation, not political barziers. In other words, it may be politically very difficult to decide to implement a national wires charge, but it could be easy for the government to implement. On 
the other hand, planning may receive widespread political support in the abstract but might be particularly difficult for govemment to achieve at the local level.

Straightforward Mechanisms

In general, govemments do not have technical difficulties in collecting revenue beyond that posed by broad public opposition to tax increases and noncompliance. Because electricity is easy to meter, governments should find it easy to collect distribution charges, energy charges, and national wires charges. General-fund revenue mechanisms are already in place. There is precedent for user fees (e.g., gasoline taxes to fund highway construction), so there is a cultural association with collecting revenue associated with a specific industry for programs associated with that industry. Govemments at all levels have experience with trust funds, with the social security and highway trust funds being prominent examples.

Govemments also have considerable experience in setting standards, issuing licenses, awarding fanchises, dealing with mortgages, and providing information. Thus, govemments can issue portfolio standards, appliance efficiency standards, building codes, and retail licenses; award franchises; guasantee and subsidize mortgages; and provide electricity-related information. Difficulties arise in deciding how strictly to set standards, who needs to apply for licenses, what tenritory a fianchise covers, what level of subsidy for a mortgage, and what information to provide. Because the subjects under question are describable and the goals of the mechanisms are clear, these difficulties can be overcome. There is a strong cultural association with govermment carrying out these activities.

Lastly, governments have a great deal of experience in running social programs. People may disagree on the effectiveness of many programs, but the govemment can provide specific benefits to qualified individuals. Thus, governments could accept full responsibility for lowincome programs from utilities and carry them out, if so decided.

In summary, government has the technicat capability to collect revenue to fund publicpolicy actions, such as low-income programs and DSM. The government has the capability to set standards to ensure minimum service, some aspects of DSM, and the use of renewable energy. Govemment has the experience to tun programs, such as low-income programs and consumer* protection programs.

\section{Moderately Difficult Mechanisms}

If the industry is deintegrated as discussed above (Fig. 2) and if FERC requires transmission owners to file and comply with open-access, comparable-service transmission tarifts (FERC 1995), then nondiscriminatory transmission access will not be a problem. However, if transmission owners continue to own generation assets and if state/FERC jurisdictional issues are not resolved, problems may occur.

The stranded-commitments issue is another one that will be moderately difficult to solve because it also occurs at the federal-state-private sector interface. Allocating costs to various parties is difficult because of the confusing morass of who ethically and legally ought to bear the 
financial burdens. Sorne people even argue that PUCs should not assign responsibilities for these stranded commitments, with some advocates of retail wheeling arguing that the markets should allocate these costs (i.e., primarily to utility shareholders). Ultimately, this issue will be a difficult one for FERC and PUCs to resolve because of the large dollar amounts involved.

The United States has made great strides at remediating environmental problems and protecting the environment. This process has not been easy. Rather, it has engendered numerous public controversies, such as those pitting endangered species against jobs in the Pacific Northwest. Risk analyses that rely on animal test results are also controversial. Decades of research are required to improve our understanding of the earth's ecosystem and human reactions to chemicals, among numerous topics. Thus, while most people agree that government is responsible for environmental protection, it may be difficult to implement new regulations because what is meant by environmental protection is not easy to describe precisely and because many potential solutions are difficult to implement. Ultimately, political processes as well as scientific information will decide on the tradeoffs between environmental protection and economic costs.

Nonprofit organizations, funded by the government, may be able to carry out responsibilities that are too cumbersome for the government itself. While these organizations may be straightforward to create, ensuring accountability is not an easy task. Not every well-meaning, nonprofit organization will behave according to plan without oversight. The tension over this issue makes these kinds of organizations difficult to initiate by government. Governments often use local community-action agencies to implement federal and state low-income weatherization programs.

Governments, because they purchase so much, wield market power. Specific government purchasing programs seek to stimulate the demand for recycled paper, for example. The U.S. Department of Energy and Environmental Protection Agency, using the federal government's purchasing power and moral suasion, worked with the major computer manufacturers to produce and market an energy-efficient line of products, called Energy Star. This is a relatively new government mechanism, which, if what the government ought to buy can be well specified, should be easy to implement. However, how much of a premium governments should pay at taxpayer expense is a difficult technical as well as political question. In addition, government procurement bureaucracies might hinder the developrnent of vibrant markets.

The United States has a history of supporting public involvement in government, including town meetings, extensive voting for public officials, referenda, legislative hearings, and executiveagency public meetings and hearings. These mechanisms are sometimes successful, sometimes not, for a variety of reasons. Governments can continue to improve in this area (e.g., through the use of facilitators, advocates, and other mechanisms). The challenge in an industry with retail competition is to create public fora where citizen inputs can make a difference on what fuels are used for generation, where new transmission lines will be located, and so on. Unfortunately, public-participation programs are moderately difficult to implement satisfactorily because describing precisely what is meant by public participation and measuring the success of these types of programs are difficult. 
In summary, government may have some difficulty in solving transmission access and stranded-commitment problems and in regulating emissions to everyone's satisfaction. It will face some difficulty in creating new institutions to deliver programs, such as R\&D and low-income assistance. Government can influence market directions (e.g., through purchasing electricity generated from renewable sources). The govemment can also arrange fora to voice concerns about the evolution of the electric industry (e.g., as related to consumer protection).

\section{Potentially Very Difficult Mechanisms}

Governments encounter much difficulty in planning. Laws protecting private property and public controversies regarding plans act as strong barriers to planning. People have mixed feelings about government planning. On the one hand, some see planning as a violation of individual freedom and property rights. On the other hand, some welcome planning if it raises their property values, reduces their congestion, and places noxious facilities far from their homes. Because people possess a wide range of values, it is often difficult to even articulate what the goals of a plan should be. For these and other reasons, urban and sustainable-development planning and state-level IRP might be very difficult for governments to achieve successfully. Current tebates over wetlands protection and the Endangered Species Act are clear examples of the conflicts anong values concening public vs private interests.

Different levels of government may find it difficult to cooperate via interstate compacts, joint state boards, and other mechanisms because of differences in values, statutory authorities, and other unique conditions. For example, states might compete with each other to attract new generation sources, whose power could be wheeled to other states. Conflicts could erupt as states pursue a downward spirai of tax and other incentives to prospective projects to increase local employment. Alternatively, states may find it easier to meet clean-air standards by having new generation sources located elsewhere, which would also produce conflicts, as is true for commercial-hazardous-waste and nuclear-waste disposal facilities.

Government-funded and -managed R\&D is controversial. Many people agree that government should support basic research and that government should not compete with the private sector in product development. Between these positions is a large gray area. For example, government-sponsored basic research should ultimately support real-world applications, but because the basic-research oufputs, in essence and in time, cannot be predicted, links to applied needs are tenuous. One way to improve this situation is to have basic researchers interact more frequently with applied researchers and the private sector. Such interactions are difficult while maintaining the quality of basic research without favoring one firm over another. The government should support research, but achieving all that it might through such prograns is dificult.

In summary, government will find it difficult to implement portfolio/risk management in a world of retail competition. Resolving conflicts over environmental objectives and transmission issues will be difficult as wil] achieving $R \& D$ success in areas that border activities taking place in the marketplace. 


\section{CONCLUSIONS}

Based on the April 1995 workshop and many other sources, we developed a framework to consider the public-policy responsibilities of the U.S. electricity industry. This proposed structure for thinking about electric-industry restructuring includes three underlying values, ten objectives, and eleven actions to achieve these objectives. The values and objectives include:

- Economic progress: economic efficiency, industrial competitiveness, economic development, and customer choice;

- Social equity: equitable sharing of costs and benefits, public participation, fair-trade safegtards, and protection of human welfare;

- Environmental stewardship: clean electricity generation and delivery and improvement of regional environmental quality.

We also defined each of the values, objectives, and actions.

These framework elements interact in complicated ways. Some actions, such as R\&D and DSM, support both economic and environmental objectives. Therefore, it is difficult to predict the extent to which market forces aimed at economic efficiency will automatically capture some of the environmental and equity objectives. Complementarity and conflict among objectives is even more likely for the long term than for the short term, given differences in public vs private discount rates, perspectives, and goals. Because of these factors, we believe that the actions might change substantially over time as the industry evolves, white the underlying values and objectives will likely remain the same.

Sorne of the actions are primarily transitional, especially treatment of stranded commitments. One way or another, this issue will be settled. Other actions, such as protection of low-income and other residential consumers, are enduring and require long-term solutions.

We next examined the likely performance of markets and the extent to which markets in a restructured retail-wheeling industry would meet public-policy objectives. Finally, we examined the possible roles of governments to either guide the industry or to directly provide public-policy services.

We are optimistic that a restructured electricity industry, with only modest government oversight, can achieve the economic-efficiency gains that its proponents claim will occur (primarily lower prices and greater choice). We are also optimistic that the new structure can 
provide the public-policy functions discussed here, although probably in ways different from those used today.

Such optimism assumes that stakeholders are open-minded, cooperative, and willing to compromise. For example, large industrial firms that have sufficient market power to extract low prices from electricity suppliers may need to give up some of those price reductions to other customer classes. Low-income and energy-efficiency advocates, on the other hand, may need to accept the idea that new actions may be appropriate to meet their underlying equity and environmental objectives. That is, they should not cling to the old mechanisms that met their objectives in the past.

The Electric Industry Restructuring Collaborative (1995) in Rhode Island demonstrates these points about cooperation and compromise. The collaborative developed a set of 17 interdependent principles to govern the transition from one industry structure to arother. The collaborative participants, which included electric utilities, industrial fitms, environmental groups, and the staff of the PUC, agreed that these principles needed to be considered as a whole. That is, the participants did not want the Rhode Island PUC to pick and choose among these principles but to accept them as an integrated, compromise package.

We sense that the public increasingly favors market actions over government actions. As evidence, we cite the defeat of President Clinton's health-care reform proposal in 1993; the November 1994 election results; opposition to tax increases of any kind; and public concern that many government programs are unwieldy, out-of-date, difficult to change, usresponsive to public interests, and too expensive (Howard 1994). On the other hand, people still want governments to protect them from the vagaries and possible abuses of unbridled market forces (Reich 1991). We see ways to navigate such a path for the electricity industry, a path that involves substantially fewer government mandates than exist today, but one that maintains considerable government oversight of the electricity industry and the public-policy functions it delivers.

Our review of the strengths and limitations of markets and governments suggests that markets will provide refiable and nondiscriminatory electric service, with only little FERC oversight required. Responsibilities for energy $R \& D$, resource-portfolio management, energy efficiency, and renewable resources will likely be shared between the industry and government regulators. We anticipate the use of different actions (mechanisms) to achieve the underlying objectives that these functions have historically met. For example, regulators may impose fewer requirements on the acquisition of energy-efficiency and renewable resources and, instead, impose stricter environmental requirements. Imposing a national cap on annual $\mathrm{CO}_{2}$ emissions might be a more effective way to reduce global warming than the indirect route of requiring certain DSM-program activities and renewable setasides. Finally, governments may have to take the lead to ensure that consumers, especially small consumers who lack market power, are treated fairly and given adequate minimum services. 
The economic-progress values are likely to be met reasonably well by a competitive electricity market, with only modest govemment oversight. Surely, economic efficiency will improve when investors are free to make their own decisions concerning the type, timing, location, and amounts of generation capacity to construct and operate. And economic efficiency will improve when consumers face price signals that accurately reflect the cost to produce and deliver power to them. In addition to improving the economic efficiency with which society produces and consumes electricity, such changes should also help industrial competitiveness and economic development for the reasons given above. Finally, increased customer choice is the keystone of a competitive market, so this aspect of economic progress will improve also. The only concests for the economic-progress value are the need for government oversight to prevent market-power abuses (e.g., because one or more generating companies has horizontal market power or because the transmission and distribution entities are able to exercise monopoly power unfairly).

The picture is much less clear for social equity. Here government will likely remain an important player. The role of the electricity industry itself may decline in this area as some of these responsibilities are shifted to the public sector. For example, today utilities often offer below-cost prices and free retrofit services to low-income customers, with the costs borme by electricity consumers in general. In the future, government agencies, rather than distribution utilities, may provide low-income services, with the costs borne by taxpayers rather than by electricity consumers. With respect to public participation, people will increasingly express their preferences with their marketplace dollars as well as with their ballot-box votes and their publichearing voices. However, governments will still need to provide opportunity for public input conceming such issues as the siting of power plants and transmission lines and the appropriate tradeoffs between environmental protection and increased electricity costs. The challenge here is to ensure that the legitimate needs of low-income people, other special groups, and society as a whole are met in a restructured indusiry.

For environmental quality, the role of PUCs may diminish, while the role of state environmental-protection agencies may increase. Also, sociely may rely more on direct programs (e.g., taxes on fossil fuels or on certain pollutants or regional or national caps on emissions of certain pollutants) and less on indirect programs, such as formal IRP proceedings and renewables setasides. The challenge is to improve economic efficiency and environmental quality simultaneously. That is, the environmental gains associated with implementation of DSM and renewable resources need to be maintained by other, perhaps more efficient, mechanisms.

Foreseeing the future of the electric industry, once it has embarked on its restructuring journey, is extraordinarily difficult. Reasoning through the altemative structures and their implications a priori is virtually impossible. Therefore, society must treat electric-industry restructuring as an empirical problem, with the wisdom to maintain institutions that can make midcourse corrections.

Finaliy, economic and equity values mix like oil and water. Markets are good at achieving efficiency but are not designed with equity in mind. Markets have also not been 
consistent with environmental stewardship, although efforts are underway to institute market mechanisms to achieve such objectives. Today's regulated utility industry synthesizes all three values - efficiency, equity, and environmental stewardship-within one institutional framework, albeit with the loss of some economic efficiency. A key challenge for the industry is to find institutional forms that improve economic efficiency while maintaining equity and envirorumental values.

\section{ACKNOWLEDGMENTS}

We thank Val Jensen for his continuing support of this project. We thank the workshop participants for their time, insights, and commitment to the socially beneficial restructuring of the electricity industry. We thank Lester Baxter, Eric Blank, Anne Eakin, Joel Eisenberg, David Festa, Paul Galen, Charles Guinn, Paul Hansen, Cheryl Harrington, Larry Hill, Val Jensen, Douglas Larson, Henry Lee, Gordon MeDonald, Michael Oldak, Kenneth Rose, Tom Stanton, and Sam Swanson for their very helpful comments on the draft of this report. We thank Fred O'Hara for editing the final seport and Ethel Schom for managing the clearance, printing, and distribution process. Finally, we thank Sheila Moore for arranging the workshop and preparing the draft report. 


\section{REFERENCES}

M. Adler 1981, Six Great ldeas, Collies Books, New York, NY.

American Wind Energy Association 1995, A Renewables Portfolio Standard, Washington, DC, Apri].

G. L. Bach 1974, Economics: An Introduction to Analysis and Policy, Prentice Hall, Englewood Cliffs, NJ.

T. Bass 1994, Reinventing the Future: Conversations with the World's Leading Scientists, Addison-Wesley, Reading, MA.

L. Baxter and E. Hirst 1995, Estimating Potential Siranded Commitments for U.S. InvestorOwned Electric Ulikities, ORNL/CON-406, Oak Ridge National Laboratory, Oak Ridge, TN, January.

R. N. Bellah, R. Madsen, W. Sullivan, A. Swidler, and S. Tipton 1992, The (iocod Soctiety, Vintage Books, New York, NY.

M. A. Brown, M. A. Beyer, J. Eisenberg, E. Papsa, and M. Power 1994, Whility /nvestments in Low-Income Energy-Efficiency Programs, ORNL/CON-379, Oak Ridge National Laboratory, Oak Ridge, TN, September.

Califomia Public Utilities Commission 1994, Onder Instituing Rulemaking on the Commission's Proposed Policies Goveming Resfmoturing Califomia's Electric Services Industry and Reforming Regulation, R.94-04-031/1.94-04-032, San Francisco, CA, Apri] 20.

California Public Utilities Commission Working Group 1995, Working Group Report, Options for Commission Consideration, R.94-04-031/I.94-04-032, San Francisco, CA, February 22.

California Public Utilities Commission 1995, Proposed Policy Decision Adopling a Preferred Indusiry Sinucture, R.94-04-031/I.94-04-032, San Francisco, CA, May 24, 1995.

L. Cullen, G. Mathis, D. Ray, and R. Stevenson 1994, Policy Options for Competition in Wisconsin's Electric Power Inthstry, Wisconsin Public Utility lnstitute, University of Wisconsin, Madison, WI, September. 
Demand-Side Report 1995, "NRDC Tries to Derail Notion that DSM Causes High California Power Rates," May 25.

Electric Industry Restructuring Collaborative 1995, Report and Set of Interdependent Principles to the Rhode Island Prblic Utilities Commission, Docket D-94-9, Providence, RI, May 12.

Electricity Consumers Resource Council 1994, "Comments of the Electricity Consumers Resource Council Before the Public Utilities Commission of the State of California," Washington, DC, June 23.

Energy Information Administration 1993, Financial Siatistics of Major U.S. Investor-Owned Electric Utilities, DOE/EIA-0437(92)/1, U.S. Department of Energy, Washington, DC, December.

Energy Information Administration 1994, Electric Power Annual 1993, DOE/ElA-0348(93), U.S. Department of Energy, Washington, DC, December.

Federal Energy Regulatory Commission 1995, Prontoting Wholesale Compefition Through Open Access Non-Discriminatory Transmission Services by Public Utilites and Recowery of Simanded Costs by Public Wilities and Transmitting Vilities, Notice of Proposed Rulemaking and Supplemental Notice of Proposed Rulemaking, Docket Nos. RM95-8-000 and RM94-7-00I, Washington, DC, March 29.

S. Hadley and E. Hirst 1995, Utility DSM Programs from 1989 Through 1998: Continuation or Cross Roods?, ORNL/CON-405, Oak Ridge National Laboratory, Oak Ridge, TN, February.

J. Hamrin, W. Marcus, C. Weinberg, and F. Morse 1994, Affected with the Puhlic Interest: Electric Industry Resinucturing in an Era of Compelinion, National Association of Regulatory Utility Commissioners, Washington, DC, September

J. P. Harris, J. Shugars, N. Casey-McCabe, and C. Payne 1994, "Energy Efficient Government Procurement: Federal Perspectives," Chapter 74 in Competitive Energy Management \& Environmental Technologies, Proceedings of the 17th World Energy Engineering Congress, Association of Energy Engineers, Atlanta, GA, December.

E. Hirst 1994, Electric Uhility DSM Progranss in a Competitive Market, ORNL/CON-384, Oak Ridge National Laboratory, Oak Ridge, TN, April.

E. Hirst and C. Sabo 199!, Electric-Uitity DSM Programs: Terminology and Reprring Forms, ORNL/CON-337, Oak Ridge National Laboratory, Oak Ridge, TN, October.

P. K. Howard 1994, The Death of Common Sense, How Law ls Suffocating America, Random House, New York, NY. 
P. L. Joskow and R. Schmalensee 1986, "Incentive Regulation for Electric Utilities," Yale Journal on Regulation 4, 1-49.

A. Kahn 1988, The Economics of Regulation: Principles and Institufions, Volume I, The MIT Press, Cambridge, MA.

S. M. Lewis and J. G. Besser 1995, "The Competitive Generation Market Has Been Assurned, Not Proven," The Electricity Joumal 8(3), 70-73, April.

D. Logan, C. Neil, and A. Taylor 1994, Modeling Renewable Energy Resources in Integrated Resource Planning, RCG/Hagler, Bailly, Inc., prepared for the National Renewable Energy Laboratory, NREL/TP.462-6436, Golden, CO, June.

W. Massey 1993/1994, "Transition to Competition: Federal Initiatives and Industry Opportunities," The Elecrricity Joumal 6(10), 26-32.

R. Nelson and G. Wright 1992, "The Rise and Fatl of American Technologıcal Leadership: The Postwar Era in Historical Perspective," The Joumal of Economic Literature 30(4), 193 I-1964

J. Newcomb 1994, The Future of Eneryy Efficiency Services in a ('ontpethive Linvironment, E Source, Boulder, $\mathrm{CO}$, May.

New York Energy Planning Board 1994, New York State Enengy Plan. Votume I: Summary Report, New York State Energy Office, New York Department of Environmental Conservation, and New York Department of Public Service, Albany, NY, October.

New York Public Service Commission 1994, "Opinion and Order Regarding Proposed Principles to Guide the Transition to Competition," Opinion No. 94-27, Case 94-E-0952 - In the Matter of Competitive Opportunities Regarding Electric Service, Albany, NY, December 22

Niagara Mohawk Power Corp. 1994, The lmpacts of Emerging Competition in the Electric Utility Indusiry, Syracuse, NY, April.

National Science and Technology Council 1994, Technology for a Sistainable Future, Office of Science and Technology Policy, Washington, DC.

A. M. Okun 1975, Equality and Efficiency, The Brookings Institution, Washington, DC.

Pacific Gas \& Electric 1992, Rewource: An Encychoedia of Enerzy (hility Terms, San Francisco, CA.

J. Rawls, 1971, A Theory of Jusice, Havard University Press, Cambridge, MA. 
R. B. Reich 1991, The Work of Nations, Preparing Ourselves for 21st-Century Capitalism, Alfred A. Knopf, New York, NY.

P. Schwartz 1991, The Art of the Long View, Doubleday, New York, NY.

M. Schweitzer, M. English, S. Schexnayder, and J. Altman 1994, Energy Efficiency Advocacy Groups: A Study of Selected Interactive Efforts and Independent Initiatives, ORNL/CON-377, Oak Ridge National Laboratory, Oak Ridge, TN, March.

S. Tiemey 1994, "Comments of the United States Department of Energy, "Before the California Public Utilities Commission, Docket No. R. 94-04-031, Washington, DC, June 8. Also, see R. Nordhaus and M. Nichols 1994, "Proposed Principles Submitted by the United States Department of Energy and the U.S. Environmental Protection Agency." Case 93-M-0229, New York Public Service Commission, Washington, DC, September 26.

B. Tonn, E. Hirst, and D. Bauer 1994, IRP and the Electric Indistry of the Furur: Workshop Resuls, ORNL/CON-398, Oak Ridge National Laboratory, Oak Ridge, TN, September. 


\section{WORKSHOP PARTICIPANTS}

Douglas Bauer

Oak Ridge National Laboratory

Eric Blank

Land and Water Fund of the Rockies

Nancy Brockway

National Consumer Law Center, Inc.

Matthew Brown

National Conference for State Legislators

Paul Centoletla

SAIC

Richard Cowart

Vermont Public Service Board

Alan Davis

Montana Department of Natural Resources

Anne Eakin

PacificCorp

Joseph Eto

Lawrence Berkeley Laboratory

Paul Galen

National Renewable Energy Laboratory

Howard Getler

American Council for an Energy-Efficient Economy

Charles Guinn

Strategic Guidance Associates

Cheryl Harrington

The Regulatory Assistance Project
Eric Heitz

Energy Foundation

Eric Hirst

Oak Ridge National Laboratory

Val Jensen

U.S. Department of Energy

John Jurewitz

Southern California Edison

Steven Kline

Pacific Gas and Electric Co.

Dale Landgren

Wisconsin Electric Power Company

Dan Mazmanian

Claremont Graduate School

David Meyer

U.\$. Department of Energy

Terry Singer

National Association of

Energy Service Companies

Tom Stanton

Michigan Public Service Commission

Sam Swanson

Energy Efficiency \& Renewables

Bruce Tonn

Oak Ridge National Laboratory

David Wooley

Pace Center of Environmental Legal Studies 



\section{DEFINITIONS}

We define each value, objective, and action listed in Table 2.

Values: Fundamental guiding principles of life. Values can be viewed as "great ideas,"such as truth, goodness, beauty, liberty, equality, and justice (Adler 198I). Commonty held fundamental values are essential bonds among people. As such, values represent building blocks of publicpolicy.

Economic propress: Continued improvement of production technologies, financial instruments, and organizational methods to provide goods and services to support a high quality of tife, provide ample employment opportunities, and satisfy environmental-stewardship and socialequity values.

Social equity: According to Rawls (197]), social equity or a just society is achieved when "(I) each person is to have an equal right to the most extensive total system of equal basic liberties compatible with a similar system of liberty for all; and (2) social and economic equalities are to be arranged so that they are both: (a) to the greatest benefit of the least-advantaged consistent with the just savings principle, and (b) attached to offices and positions open to all under conditions of fair equality of opportunity."

On economic equality, Okun (1975) wrote "more or less equality as implying smalter or greater disparities among families in their maintainable standards of living, which in turn implies lesser or greater disparities in the distribution of income and wealth, relative to the needs of families of different sizes." On equality of opportunity, he wrote that "it is rooted in the notion of a fair race, where people are even at the starting line ... but it is hard to find the starting line. Differences in natural abilities are generally accepted as relevant characteristics that are being tested in the race rather than as unfair head starts and handicaps. At the other extreme, success that depends on whom you know rather than what you know is a clear case of inequality of oppottunity."

Environmental stewardship. Protection of the earth's physical environment, ecosystems, plants and animals, and diversity of natural resources for future generations. The impetus for environmental stewardship flows pritrarily from ethical concerns and must be balanced with economic and equity values. 
Objectives: Broad goals related to the expression of the fundamental values.

Economic efficiency: "... the optimal production and consumption of goods and services economic efficiency generally occurs when the prices of products and services are equal to their marginal costs. If this condition is not met, then from society's perspective, economic (or social) welfare is not maximized" (Pacific Gas \& Electric 1992). Markets are often better at achieving economic efficiency than is the administrative determination of prices. With respect to the electric industry, economic efficiency refers to the optimal production, transmission and delivery of electricity. To create the appropriate price signals, a restructured industry must be able to accommodate new pricing options for unbundled and rebundled electricity services.

Industrial competitiveness: The relative ability of a national economy and individual industries to produce goods and services at lower cost and higher quality than other nations and their industrial sectors. Factors contributing to industrial competitiveness include: development and application of advanced technologies; science and technology education and training; availability of resources; and availability of large markets (Nelson and Wright 1992). A more efficient electric industry, with resuiting lower electricity prices and greater consumer choice, could be an important factor in the overall U.S. industrial competitiveness.

Economic development: The ability of an economy to produce a larger output over time (Bach 1974), to increase employment opportunities, and to increase the value of the goods and services produced over time. For the electric industry, economic development refers to the industry's ability to provide the amounts and types of electricity services required by other sectors of the economy at prices that are less than the value of these services.

Customer choice: A combination of the availability of a wide variety of goods and services and the ability of consumers to make informed choices among those goods and services, given inoome constraints. Markets provide a means for firms to be responsive to customer preferences. For the electric industry, customer choice refers to the availability of alternative suppliers of electricity and electricity services and the ability of consumers to choose among these suppliers without government intervention.

Equitable sharing of costs and benefits: This objective requires fairness across socioeconomic classes, geographic locations, and time (intergenerational equity). For the electric industry, restructuring decisions should be equitable across income levels, retail-customer classes, and the entities that own, regulate, and consume the outputs from electricity-production facilities.

Public participation: A community-based process in which citizens, in cooperation with their elected officials and government representatives, identify important community problems, voice their opinions and concerns, express their values and beliefs. contribute to the development of solutions to the problems, and judge the costs and benefits of potential solutions to ultimately render decisions. 
Because IOUs have traditionally operated as regulated monopolies, the public has always been allowed some say concerning their affairs. The public is represented (at least in theory) by PUCs that exercise control over prices and tariffs, resource procurement, and similar topics. More directly, members of the public (especially organized interest groups) can-and frequently do-advocate their position in regulatory proceedings. In addition to these formal and wellestablished avenues for influencing utility actions, there are a number of other ways that the public can affect decisions. These include utility use of focus groups, workshops, advisory groups, and collaboratives (Schweitzer et al. 1994). In competitive markets, public participation is replaced primarity by customer choice. Because customers have choices, suppliers work hard to be responsive to customer wants. The key differences between public participation and customer responsiveness are whether producers respond to individual consumers or to community aggregates and whether such decisions are made primarily in the marketplace or in the political arena.

Fair-trade safeguards: Characterized by the absence of seller misrepresentation, discrminatory price cutting, restraint of trade, pricing below cost, monopoly powers, price fixing, and artificial market allocation and production limitation (Bach 1974). Ensuring fair trade requires oversight by state attorneys general and federal agencies, such as the Federal Trade Commission and the Department of Justice. State PUCs have historically overseen fair trade by utility monopolies. As competition rises in the industry, other fair-trade problems related to discriminatory pricing to keep industrial customers from cogenerating and/or leaving service territories are surfacing.

Protection of human welfare: Refers to promotion of safety, protection of human health, and assurance that every individual has access to the basic necessities of life, including food, shelter, and clothing. Because electricity is central to the protection of human welfare, minimal consumption levels should not be denied when human heal th and safety are at risk.

Clean electricity generation and delivery: Implementation of processes and techniques to reduce and possibly eliminate the emission of poliutants and risks to human and ecological health associated with the generation, transmission, and distribution of electricity. This objective directly satisfies environmental objectives related to reducing acid deposition and global warming, abating regional ozone problems, and disposing of hazardous and radioactive wastes and to human-health objectives related to electromagnetic fields.

Regional environmental quality: Pertains to environmental-quality considerations that are primarily external to the electricity industry. Utilities can work with firms in other industries and with local and state governments to improve regional environmental quality. For example, the participants can meet regional air-quality goals through arrangements to coordinate working hours and production suns to reduce the need to use "dirty" generation resources. In addition, utilities can help solve customer environmental problems (e.g., use of clean electrotechnologies to replace direct use of fossil fuels). 
Actions: Purposeful behaviors intended to achieve objectives. Actions are tangible and involve people doing things.

Besearch and development: " $\mathrm{R}$ and $\mathrm{D}$ are totally different. $\mathrm{D}$--development-is knowing where you want to get to and what you have to do to get there. But for this R bit-although you think you know where you'd like to get to, you're not at all sure how to get there. The development process responds to hierarchial managernent, to whipping, kicking and pushing. But it's inconceivable that you can make research go that way ${ }^{\text {n }}$ (J. Black, as cited in Bass 1994).

System_reliability; Reliability is "a measure of a system's ability to deliver uninterrupted service" (Pacific Gas \& Electric 1992). Reliability measures for generation are generally probabilistic (e.g., 1-day-in-10-years loss of load probability), and for transmission and distribution are deterministic (e.g., N-l contingency considerations)

Ponffolio/risk management: Refers to strategies, plans, and decisions that seek to allocate and manage risk across a spectrum of activities with respect to a range of possible future states of the world. Fuel and technology diversity are important tools for portfolio/risk management in the electric industry (Logan, Neil, and Taylor 1994). Risk of fuel-supply disruptions, economically disruptive energy-price increases, and untoward environmental degradation can be minimized by employing a broad portfolio of energy supply and demand resources to provide electric-energy services. Portfolio and risk management entail key choices between short- and long-term considerations (e.g., balancing the low prices of natural gas in the short term vs the possibility of higher prices later on.)

Demand-Side Management: DSM programs are organized utility activities that affect the amount and timing of customer use. Traditionally, utilities have focused their DSM proyrams on five objectives: energy efficiency, peak clipping, load shifting, valley filling, and load building (Hirst and Sabo 1991). Energy-efficiency programs are aimed at reducing the energy used by specific end-use devices and systems without regard for the timing of program-induced savings. Peakclipping programs are aimed at reducing electsicity demand at certain critical times, typically when the utilify experiences system peaks. Load-shifting programs aim to move electricity consumption from one time to another (typically from on-peak to off-peak periods during a single day). Valley-filling programs typically seek to increase off-peak electricity use. And loadbuilding programs (often called beneficial electrification) aim to increase electricity consumption. Utilities, regulators, environmental groups, and others are interested in DSM because of its resource value (providing $\mathrm{kWh}$ and $\mathrm{kW}$ benefits that can substitute for some power plants), its environmental benefits, and its customer-service benefits.

Nondiscriminatory transmission access: Institutions to achieve this objective, such as RTGs, should have these characteristics: "Allow for membership by all buyers and sellers of transmission services; contain an area large enough and contiguous enough to allow for reliable, efficient and competitive transmission services; require members to provide transmission service to other members, even when system expansions are needed; require members to develop and update a regional transmission plan; include fair and nondiscriminatory governing procedures 
and voluntary dispute resolution procedures; and provide for adequate consultation and coordination with state regulators" (Massey 1993/1994).

Low-income prossams: Includes activities to: reduce "heating and cooling costs for low-income households, particularly for the elderly, people with disabilities, and children, by improving the energy efficiency of their homes and ensuring their health and safety" (Brown et al. 1994); provide low-income rate assistance, which can be a "program that provides qualified low-income residential electric ... customers with a ... reduction in their ... rates" (Pacific Gas \& Electric 1992) or direct payments of bills to low-income households; and prevent disruption of electricity services during acute weather events (e.g., a winter moratorium program is one where "[u]tilities are prohibited from shutting off power to a customer during the cold winter months, whatever their arears. This increases the utilities' bad debts, and this loss of revenue must be made up by other customers" (Cullen et al. 1994).

Minimum service standards: State regulators specify requirements that electric utidities must meet. These standards typically cover public safety, technical specifications for power quality at the customer's meter, consumer protection, and customer service. Safery standards are intended to protect utility employees and the public at large from accidents caused by the utility's electrical systems; such standards may specify minimum strength of utility power poles, minimum clearance between utility equipment and structures, and minimum distances between conductors on a utility's distribution system. Technical specifications might include maximum ranges for voliage and frequency at the customer meter (e.g., a range of 117 to 125 volts for single-phase service). Customer-protection standards may include specifications on the accuracy of electric meters (e.g., accurate to within 1\%), limits on termination of service (e.g. a moratorium during the winter), and grievance procedures to resolve customer complaints about bills, service, or other matters. Customer-service requirements might include specifications on the promptness and quality of the utility's customer-service centers and outage-restoration services.

Consumer protection: Represents the goal of providing consumers with legal and/or financial wherewithal to protect their rights and interests in disputes with corporations. This is the key mechanism used to ensure fair trade among suppliers and between suppliers and different groups of customers.

Eair treatment of stranded commitments: Utilities may have stranded commitments when loss of revenue, because of competition, fails to cover costs and when utlities are bound to uneconomic commitments (Baxter and Hirst 1995). Stranded commitments include: stranded assets; stranded liabilities; regulatory assets; and stranded public-policy programs (Niagara Mohawk Power Corp. 1994). Fairness is a consideration when considering who pays for stranded commitments.

Benewable energy: "Renewable energy resources are naturaily replenishable, but flow-limited. They are virtually inexhaustible in duration but limited in the anount of energy that is available per unit of time ... renewable energy resources include biomass, hydro, geothermal, sotar, and 
wind. In the future they could also include use of hydrogen fuels, ocean thermal wave and tidal action technologies" (Hamrin et al. 1994).

Pollution reduction: Refers to technologies for environmental remediation and restoration, poliution control, pollution monitoring and assessment, and pollution avoidance (National Science and Technology Council 1994). With respect to the generation, transmission, and distribution of electricity, pollution-reduction technologies include stack scrubbers, technologies to monitor the emissions of $\mathrm{NO}_{x}$ and $\mathrm{SO}_{2}$, clean-coal technologies, and use of cleaner fuels Other methods include different ways to operate (schedule and dispatch) generating units to minimize the emission of air pollutants. 